\title{
Sürdürülebilir Bir Yönetim Paradigması: Ortopedik Engelli Bireylerin Afetlere Hazırık Seviyeleri
}

\author{
Kasım YILMAZ ${ }^{1}$, Bora BALUN ${ }^{2}$ ve Gazanfer ERBAY ${ }^{3}$
}

\section{Öz}

Doğa veya insan temelli olarak meydana gelen afetler, nerede, ne zaman, nasıl ve hangi büyüklükte ortaya çıkacağı önceden tam olarak kestirilemeyen olaylardır. Ortaya çıkış biçimine göre bireysel veya kitlesel, sosyo-ekonomik ayrım gözetmeksizin oldukça geniş etki yaratabilen afet ve acil durumlar; başta insanlar olmak üzere canlılar ve çevre açısından ekonomik ve sosyal zararlara yol açabilmektedir. İnsan, çevre ve diğer canlılar açısından telafisi mümkün olmayan sonuçlara yol açan afetler olmadan önce özel bir çaba ve hazırlık sürecini gerektirmektedir. Bu hazırlık sürecinde engelli bireylerin, kendilerine özel önem atfedilmesi gereken bir kitleyi oluşturdukları düşünülmekte; karar vericiler tarafından üretilen plan, program ve politikalarda ayrıca dikkate alınmaları gerektiği savunulmaktadır. Afet ve acil durumlar açısından özel öneme sahip engelli bireylerin, bu tür olaylara bireysel hazırlık seviyelerinin ölçülmesinin amaçlandığı bu çalışmada, Karabük ilinde ikamet etmekte olan 322 ortopedik engelli bireye; İnal (2015) tarafından geliştirilen, 33 maddeden oluşan "Sağlık İnanç Modeli 'ne Dayalı Acil Durumlara/Afetlere Bireysel Hazırlık Ölçeği" uygulanmıştır. Araştırma neticesinde engelli bireylerin afet ve acil durumlar konusunda farkındalık odaklı özel bilgilendirme ve eğitime intiyaç duydukları tespit edilmiştir. Engelli bireylere yönelik hazırlanacak olan afet ve acil durum plan, program ve politika süreçlerinde bireylerin engel derecesi ve engel grupları dikkate alındığı takdirde hedeflenen başarı seviyesinin yükseltilebileceği düşünülmektedir.

Anahtar Kelimeler: Acil durum, afet, afetlere bireysel hazırlık, engelli birey

\section{A Sustainable Management Paradigm: Personal Disaster Preparadness Levels of People With Disabilities}

\begin{abstract}
Human or nature related disasters are usually unpredictable events of which time, place and impacts are difficult to forecast. Disasters and emergencies may have wide and severe impacts on lives regardless of individual or socio-economic distinctions of people and lead to economic, social and environmental damages. It requires a special effort and preparation process before disasters happen and cause heavy consequences for human and environment. In this preparation process, people with disabilities are thought to be a special group which should be given an extraordinary attention to. In overall disaster and emergency planning, decision makers should take people with disabilities into consideration in organizational program and policy making processes. In this study, it is aimed to measure the personal preparedness levels of individuals with disabilities living in Karabük for disasters and emergencies. A total of 322 disabled person living in Karabük was reached and surveyed about their personal disaster and emergency preparedness levels. In this survey a 33-item "Health Belief Model based Personal Disaster
\end{abstract}

\footnotetext{
${ }^{1}$ Dr. Öğretim Üyesi. Karabük Üniversitesi, TOBB Meslek Yüksek Okulu, Karabük, Türkiye

2 Doktora Öğrencisi. Anadolu Üniversitesi, Çalışma Ekonomisi ve Endüstri İlişkileri Anabilim Dalı, Eskişehir, Türkiye

3 Dr. Karabük İl Afet ve Acil Durum Müdürlüğü, Karabük, Türkiye

*ilgili yazar / Corresponding author: borabalun@hotmail.com

Gönderim Tarihi: 22.03.2019
}

Kabul Tarihi: 29.06.2019

Yılmaz, K., Balun, B., \& Erbay, G. (2019). Sürdürülebilir Bir Yönetim Paradigması: Ortopedik Engelli Bireylerin Afetlere Hazırlık Seviyeleri. Resilience, 3(1), 1-24. 
Sürdürülebilir Bir Yönetim Paradigması: Ortopedik Engelli Bireylerin Afetlere Hazırık Seviyeleri

A Sustainable Management Paradigm: Personal Disaster Preparadness Levels of People With Disabilities

and Management Preparedness Scale" developed by Inal (2015) was used. As a result of the study, it has been determined that disabled individuals need special information and educational support focused on disaster and emergency situations. It was considered that taking the level and group of disabilities of people into consideration while preparing emergency plan and policies would increase the chance of success of recovery in disasters and emergencies.

Keywords: Disaster, emergency, individual disaster preparedness, person with disability

\section{GíRiş}

Doğal ve insan kaynaklı afetler doğrudan veya dolaylı etkileriyle toplumlar üzerinde sosyal ve ekonomik tahribatlara neden olmaktadır. Ortaya çıkan tahribatın müdahalesi ve yönetimi, özen dikkat ve uzmanlık gerektirmektedir. Söz konusu afetlerde, toplumsal reaksiyon ve afetin toplum ve bireylerce nasıl algılandığını anlamlandırmak, afet olaylarına hazırlık aşamasının önemli unsurları arasındadır.

$\mathrm{Bu}$ doğrultuda, afet farkındalığı yaratarak toplumsal bilinç düzeyinin yükseltilmesi ve geliştirilmesi çalışmaları, afet olaylarına karşı birey ve toplumu daha da hazır bir konuma taşırken; afet sonrası aşamasına yönelik çabaların koordinasyonu açısından birey, toplum, devlet, sivil toplum kuruluşları vb. unsurlara da ilave sorumluluklar yüklemektedir. Türkiye gibi afet olaylarının sıklıkla karşılaşıldığı ülkelerde bu sorumluluk daha da anlam kazanmaktadır.

Afetler, Türkiye açısından defakto bir kavram olup, hayatın gerçeği olarak kabul edilmektedir. Bu konuda ülkemizde yürütülen bilimsel çalışmalar mevcut gerçeği doğrular nitelikte olup; AFAD tarafından 2014 yılında gerçekleştirilen saha araştırmasına dayalı bir çalışmada, Türkiye'de yaşayan bireylerin yaklaşık 1/4'ünün doğrudan herhangi bir afet olayına maruz kaldıkları bulgularına yer verilmiştir. Aynı araştırmaya katılan deneklerin \%61'inin yaşadıkları bölgede meydana gelebilecek afetler konusunda endişe taşıdıkları tespit edilmiştir (AFAD, 2014, s. 11).

Afet risklerine yönelik yayımlanan uluslararası raporlar Türkiye'nin konumunun anlaşılmasında fikir verebilecek niteliktedir. Birleşmiş Milletler ve Avrupa Birliğinin ilgili organlarının işbirliğiyle hazırlanan küresel düzeyde afet ve insani krizlerin risk seviyelerine göre derecelendirildiği "Risk Yönetim Endeksi (Index for Risk Managamenet/INFORM)" 2019 yılı raporunda Türkiye 4,9 INFORM endeks puanına (orta derece risk seviyesinde) sahip olduğu tespitlerine yer verilmiştir (INFORM, 2019, s. 11-14).

Afetlerden kaynaklanan olumsuz etkilerin tamamını etkisiz hale getirmek mümkün görünmemesine rağmen; bilgiye dayalı afet yönetimi stratejileri aracılığıyla hazırlanan planlar ve zarar azaltma odaklı çalışmalar, afetlerin negatif sonuçlarını azaltma konusunda yol gösterici olabilir (Seneviratne, Baldry ve Pathirage, 2010, s. 380). Bu noktada birey, aile, devlet ve sivil toplum kuruluşlarını da içeren geniş tabanlı katılımla afetlerin negatif etkilerinin minimum seviyeye indirgenebileceği savunulmaktadır. Engelli bireylerin bu sürecin önemli birer aktörleri ve tarafı oldukları, engelli bireylerin aktif katılımlıya başarı oranının artabileceği vurgulanmaktadır (AFAD, 2011, s. 8).

\section{AFET ve TOPLUM}

Afetler tüm dünyada ciddi oranda can ve mal kayıplarına yol açmaktadır. Afet istatistiklerine göre 2012 yılı içerisinde dünya genelinde toplam 357 afet meydana gelmiştir. Bu afetlerde 9,655 kişi hayatını kaybetmiş, 124,5 milyon insan mağdur mağdur olmuştur. Afetler neticesinde 
hesaplanan ekonomik kayıplar ise 157 milyar dolar civarındadır. 2012 yılında meydana gelen afetlerin çoğu yoksul ülkelerde meydana gelmiştir. Afetlerin en çok meydana geldiği kıta ise Asya olmuştur (Ersoy, 2013).

24 Ocak 2019 tarihinde Birleşmiş Milletler Afet Riskini Azaltma Ofisi (UNISDR) ve Afet Epidemiyolojileri Araştırma Merkezi (CRED) tarafından, 2018 yılı içerisinde meydana gelen afetlerle ilgili olarak yayınlanan verilere göre 2018 yılı içerisinde dünyada 281 adet afet olayı kayıt altına alınmıştır. Bu olaylar sonucunda dünya genelinde 10,733 kişi hayatını kaybetmiş, 60 milyondan fazla insan afetlerden olumsuz etkilenmiştir. Afetler neticesinde en fazla can kaybı 4535 kişiyle Endonezya'da ve 1388 kişiyle Hindistan'da yaşanmıştır (AYAYDER, 2018).

Afetler çok sayıda acil durum yaratan, milli düzeyde kaynakların bile yetersiz kalabileceği, aniden gelişen, şiddeti ve etki sahası çok geniş olabilecek olaylardır. Acil durumlar hızlı ve özel müdahaleyi gerektiren beklenmedik olaylardır. Afetler bazen bir ülkenin bütün kaynaklarını tehdit edebilen, büyük can ve mal kayıplarına yol açabilen doğal veya insan kaynaklı beklenmedik ve istenmedik olaylardır (Akyel, 2005).

Acil durumlar gündelik hayatın bir parçası olarak sık sık karşılaştığımız olaylardır. Sağlık acil durumları, trafik veya iş kazaları ve yangınlar acil durumlara örnek olarak gösterilebilir. Afetler esas itibarıyla acil durumlar toplamıdır. Ortaya çıkardığı sonuçlar itibarıyla insan toplulukları ve yerleşim yerleri üzerinde kayıplar meydana getirebilmekte, hayatın normal akışını durdurabilmekte veya kesintiye uğratabilmektedir (Özcan, 2011).

Afetler toplumda bir kriz hali doğururlar. Kriz hali istenmeyen, beklenmedik şekilde aniden ortaya çıkan, sahip oldukları belirsizlikler nedeniyle yönetilmesi güç, zaman baskısı altında karar verilmesini gerektiren ve toplumların veya kurumların varlığını ve hedeflerini tehdit eden durumlardır (Genç, 2008). Kriz halinin en az zararla atlatılabilmesinin yolu ise başarılı bir risk yönetimini içeren ve afetler olmadan önce yapılacak planlama ve hazırlık çalışmalarıdır.

Risk yaklaşımında belirsizlik içeren muhtemel olayların yaratabileceği etkiler, o olayların olma intimalleriyle bir arada değerlendirilerek risklerin derecelendirilmesi sağlanmaktadır.

Dünyada gözlenen afet türleri sebeplerine göre aşağıdaki gibi genelde (5) grup altında sınıflandırılmaktadır.

a. Jeolojik Afetler: Deprem, kaya düşmesi, volkanik hareketler, tsunami vb.,

b. Klimatolojik Afetler: Kuraklık, aşırı sıcak veya soğuk hava dalgaları, kasırga, sel vb.,

c. Biyolojik Afetler: Erozyon, orman yangınları, salgınlar, böcek istilaları vb.,

ç. Sosyal Afetler: Savaşlar, terör saldırıları, göçler vb.,

d. Teknolojik Afetler: Maden kazaları, biyolojik, nükleer ve kimyasal silahlar ve kazalar, sanayi ve ulaşım kazaları vb. (Hawe vd., 2012).

Afetlere karşı hazırlıklı olmanın en ideal yolu toplumun eğitim ve gelir düzeyinin arttırılarak güçlendirilmesi ve çevrenin sağlıklı kılınmasıdır (Dedeoğlu, 2011). Afet yönetimi insanların çevrelerinde gelişebilecek afetler konusunda bilgili olmaları, bu olayların gerçekleşmesi durumunda sonuçlarından hiç etkilenmeme veya en az etkiye maruz kalma bakış açısıyla yapılan çalışmaların tümüdür. Modern afet yönetiminde afet öncesi hazırlık ve korumaya yönelik çalışmalar risk yönetimi, afet sonrası çalışmalar ise kriz yönetimi olarak kabul edilmektedir. Afet yönetimi afetlerin önlenmesi ve zararlarının azaltılabilmesi amacıyla tehlike ve risklerin 
Sürdürülebilir Bir Yönetim Paradigması: Ortopedik Engelli Bireylerin Afetlere Hazırık Seviyeleri

A Sustainable Management Paradigm: Personal Disaster Preparadness Levels of People With Disabilities

tanınmasını, olaylar olmadan önce en akılcı yöntemlerle önlem alınmasını, afetler meydana geldikten sonra da toplumsal hayatın en kısa süre içerisinde normal akışına kavuşabilmesini hedefleyen topyekûn bir mücadele sistemidir. Bu mücadelede toplumun en sade bireyinden yetkili makamlara kadar herkese bir görev ve sorumluluk düşmektedir (Erkal ve Değerliyurt, 2009).

Kökenlerine bakmaksızın tüm afet olaylarıyla ilgili yönetsel faaliyetler dört aşamaya ayrılırlar (Işık vd., 2012):

1. Zarar azaltma,

2. Hazırlıklı olma,

3. Müdahale,

4. Iyileştirme.

Afet yönetim süreci yukarıda belirtilen aşamalara sahip olan bir döngüdür. Zarar azaltma afet yönetiminin adeta köşe taşı konumundadır. Afet riskleri göz önünde bulundurularak, toplum hayatının fiziki altyapısını daha yüksek standartları gözeterek gerçekleştirmek, yer seçimi ve yapılaşmada afetlerin tehlikelerini göz önünde bulundurarak tedbirler geliştirmek, yasal ve ekonomik vasıtaları düzenlemek, bireysel ve kurumsal eğitimler yoluyla afet konusunda ortak bir kültür oluşturmak çabalarıdır (Gülkan vd., 2003).

Hazırıklı olma esas itibarıyla planlama faaliyetidir. Afetlerin ortaya çıkarabileceği her türlü sonucu göğüslemeye karşı alınacak tedbirlerin planlanması, ilgili kişi kurum ve paydaşların eğitilip seferber edilmesi ve pratik yapılması faaliyetleridir. Hazırlık aşaması liderlik, eğitim, harekete hazır olma, vatandaşların güçlendirilmesine yönelik yapılacak çalışmalar ve tatbikatların desteklenmesi ve eşgüdüm konularının tamamını kapsar (Haddow vd., 2008).

Müdahale afetle birlikte ortaya çıkan ihtiyaçları hızla belirleme, çok yönlü iletişim teminiyle yeterli miktarda eğitimli personel ve gereçleri afet alanına hızla eriştirme, acil sağlık hizmetlerinin ve günlük yaşam destek tedbirlerinin gerçekleştirilmesi faaliyetleridir.

İyileştirme ise afet sonrası hayatın normale en kısa sürede döndürülmesine matuf çalışmalardır. Toplumun eğitimi, sosyal veya psikolojik yönden desteklenmesi ve muhtemel yeni afetlere karşı dirençliliğin arttırılması gayretleridir (Yılmaz, 2013).

Afet yönetimi afetlerin önlenmesi veya zararlarının azaltılması amacına matuf olarak afet döngüsü içerisinde yer alan zarar azaltma, hazırlık, müdahale ve iyileştirme aşamalarının gerektirdiği çalışmaların planlanması, yönlendirilmesi ve koordinasyonudur.

Birleşmiş Milletler Teşkilatıyla birlikte Asya kıtasında afetlerin etkilerinin azaltılması amacına matuf olarak çalışan Asya Afet Hazırlık Merkezi (ADPC) tarafından 2005 yılında yayımlanan rapora göre 'Toplam Afet Risk Yönetimi' yaklaşımı, Asya kıtasında ve tüm dünyada afetlerin etkilerinin azaltılması konusunda etkili, stratejik bir yaklaşım olarak tanımlanmaktadır. Toplam Afet Risk Yönetimi yaklaşımının iki temel prensibi bulunmaktadır. Birincisi tüm paydaşların süreçlere dahil edilmesi, ikincisi ise afet yönetiminin tüm aşamalarının (zarar azaltma, hazırlık, müdahale ve iyileştirme) tam manasıyla uygulanmasıdır. Toplam afet risk yönetim stratejisiyle; 
a. Afet azatımı konusunda yasal çerçeve ve koordinasyon mekanizmalarının oluşturulması,

b. Afet azatlım yaklaşımının kalkınma planlarıyla entegrasyonu,

c. Bilgi paylaşımı ve yönetiminin geliştirilmesi,

ç. Eğitimin ve toplumsal duyarlılığın arttırılması hedeflenmektedir (ADPC, 2005).

Afet yönetiminin afet olmadan önceki safhaya ilişkin temel hedefleri;

- Mümkünse afeti önlemek, değilse toplumun en az kayıpla afetleri atlatabilmesi için gereken teknik, yasal ve yönetsel önlemleri almak,

- Kurtarma, ilk yardım ve iyileştirme çalışmalarının hızlı, verimli ve etkili biçimde gerçekleştirilebilmesini planlamak,

- Zarar azaltma çalışmalarını kalkınmanın her aşamasında dikkate alarak, sürdürülebilir kalkınmayı gerçekleştirmek,

- Toplumun her kesiminin afetlerin etkilerinden en az zararla kurtulabilmesi için gerekli bilgilerle donatılmasını ve eğitilmesini sağlamaktır (Arca, 2012).

Afetlere karşı toplumsal direncin arttırılması gerekmektedir. Toplumsal direncin arttırılması etkili bir kamu yönetimini gerekli kılmaktadır. Ayrıca yoksulluk afetlere karşı toplumsal direncin arttırılmasını engelleyen en önemli sebeplerden birisidir. Birleşmiş Milletlerin 2015 yılında 193 ülkenin katılımıyla gerçekleştirdiği Sürdürülebilir Kalkınma Zirvesinde 2030 gündemi temel hedefler olarak; yoksulluğa ve açlığa son verilmesi, sağlıklı bireyler, nitelikli eğitim, toplumsal cinsiyet eşitliği, temiz su, hijyen ve halk sağlığı, erişilebilirlik, temiz enerji, insana yakışan iş ve ekonomik büyüme belirlenmiştir. Bu raporda özellikle yoksulların afetlere karşı kırılganlıklarının azaltılması gerektiğine işaret edilmektedir (Özer, 2016).

Afet öncesi dönemde yapılan yönetim çalışmaları risk yönetimi kavramı altında ifade edilmektedir. 2012 yılında Birleşmiş Milletler tarafından Rio de Janeiro'da yapılan sürdürülebilir kalkınma konferansında "Afet Riskinin Azaltılması" konusuna da yer verilmiştir. Sonuç raporunda afet riskinin azaltılması ve afetlere direncin arttırılabilmesi konularının sürdürülebilir kalkınma ve yoksulluğun ortadan kaldırılması politikalarına paralel olarak öncelikle ele alınması, her düzeydeki politika, program ve bütçelerle bütünleştirilmesinin gerekliliğinin altı çizilmiştir (Özkaya, 2016).

Afetlere karşı dirençlilik bir topluluğun ve sistemin sosyolojik, psikolojik ve fiziksel kapasitesi ile afetlerin ve acil durumların üstesinden gelebilme, en az zararla atlatabilme ve denge durumuna tekrar ulaşabilme yeteneğidir. Afet dirençliliği bireysel ve çevresel faktörlerle yakından ilişkilidir. Afetlere karşı toplumsal dirençliliğin mevcudiyeti meydana gelen olayların afet boyutuna sıçramamasını da etkileyen önemli bir kabiliyettir (Varol ve Kırıkkaya, 2017).

Afet yönetiminde Zarar Azaltma aşaması büyük önem taşımaktadır. Afete dönüşme riski taşıyan tehlikeler çok çeşitli olabilir. Tehlike, can ve mal kaybının yanı sıra sosyo-ekonomik düzen ve etkinliklere, tabi ve kültürel kaynaklara zarar verme potansiyeli olan her şey olarak tanımlanmaktadır (Kadıoğlu, 2008). Bir tehlikenin tahmini olumsuz etkisi ise riski oluşturur. Kişilerin malların ya da çevrenin bir tehlike etkisiyle kayıp, yaralanma ve hasara maruz kalma seviyesi ise zarar görebilirlik derecesiyle alakalıdır. Zarar görebilirlik literatürde savunmasızlık veya hassasiyet olarak ta adlandırılmaktadır. Zarar azaltma aşamasında ya tehlike ortadan kaldırılmalı, yapılamıyorsa riski azaltabilmek için hassasiyet/savunmasızlık azaltılmalıdır (Şekil 1.). 


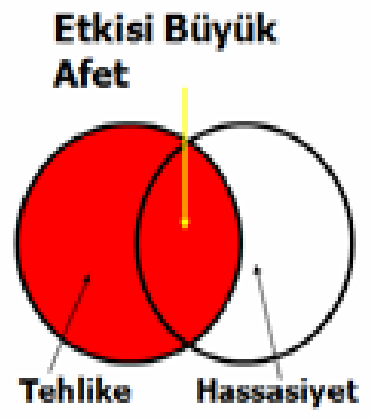

Büyük Risk

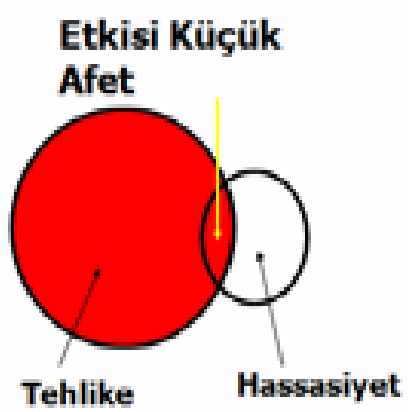

Küçük Risk

Şekil 1: Afetlerde Tehlike, Hassasiyet ve Risk İlişkisi (Kadıoğlu, 2008).

Zarar azaltma uygulamaları, afetlerle ilgili riskleri yönetebilmeyi mümkün kılmayı hedeflemektedir. Riskin nitelik ve niceliğinin tanımlanabilmesi, tehlikenin tanımlanmasını, hassasiyet oranlarının tahmin edilebilmesini gerektirir. Risk yönetimi belirlenen risklerin bir afete dönüşmeden atlatılabilmesi amacına uygun olarak alınacak önlemler ve yapılacak çalışmaların bir plana uygun olarak gerçekleştirilmesidir (Güler, 2008).

Afetlere müdahalede yaşanan tecrübeler, afetler neticesinde ulaşım ve haberleşme sistemlerinin felç olması, profesyonel kurtarma ekiplerinin yeterli miktarda bulunamaması ve idari komuta sisteminin fonksiyonel olamaması neticesinde müdahalede yetersiz kalındığını göstermektedir. Halbuki afetzedelerin hayatta kalma intimalleri Altın 72 saat olarak adlandırılan ilk üç günden sonra oldukça düşmektedir. Hayatta kalma olasılığı ilk 24 saatte kurtarılanlar için \%90, 25-48 saat aralığında kurtarılanlar için \%50, 49-72 saat aralığında kurtarılanlar için \%20, 72 saat sonrasında kurtarılanlar için ise $\% 5$ 'ten daha az olarak gerçekleşmektedir. Bu yüzden hazırlık ve müdahale aşaması zamanla yarışın gerçekleştiği, önceden kaynak ve kabiliyetlerin oluşturulması ve koordinasyonu gereken bir diğer önemli aşama olarak karşımıza çıkmaktadır (Huang ve Lien, 2012).

Özellikle yerel kaynak ve kabiliyetlerle başa çıkılamayacak şiddette etki doğuran afetlere müdahalede ilk 72 saat oldukça kritik ve önemli bir süredir. ABD'de Katrina kasırgasında yaşandığı üzere milli düzeyde kurtarma birlikleri alana erişene kadar geçen sürede, afetin başlangıcından itibaren vatandaşlar bir süre kendi başlarının çaresine bakmak durumunda kalabilmektedirler. Bu durum toplumun afetlere karşı direncinin sivil inisiyatifler kullanılarak yükseltilmesi gerekliliğinin de bir kanıtıdır (Dourandish, Zumel ve Manno, 2007).

Afetlere karşı toplumsal direncin arttırılabilmesi için uygulanan metotlardan birisi "Vatandaş Afete Hazırlık Eğitim Programlarıdır". Bu programlar temel hazırlık, yerleşim yeri müdahale timleri ve ileri düzey eğitim şeklinde farklı düzeylerde eğitimi içermektedir. Temel eğitim vatandaşların afetlere karşı evlerinde kişisel hazırlık yapmaları, acil paketleri hazırlamaları, kişisel tahliye planlamaları yapmaları ve değişik afet türlerinde hareket tarzları konularında eğitimlerini kapsamaktadır. Yerleşim yeri düzeyinde eğitimlerde toplanma alanı, yerleşim yerinde müdahale ekipleri oluşturma, lider belirleme, hasar tespiti ve enerji kaynaklarının güven altına alınması, acil haberleşmesi, ilk yardım, barınak ve özel ihtiyaçlar konularında planlama ve eğitimler yapılmaktadır. İleri düzey eğitimlerde vatandaşlardan yangına müdahale, arama ve kurtarma, olay yeri yönetimi, ilk yardım gibi konularda fiili olarak faydalanma hedeflenerek eğitimler sağlanmaktadır (Lichterman, 2000). 
Afet risk yönetimi, tanım olarak kapsayan unsurlarından hareketle değerlendirildiğinde; en küçük yerleşim biriminden ülke geneline doğru yayılım gösteren skalada; tehlike ve risklerin belirlenmesi, analizi ve tespit edilen risklerin olası negatif etkilerini minimum düzeye indirgemek amacıyla üretilen politikaların eyleme geçirilmesine salık veren bir hedef olarak benimsenmesi gerektiği anlaşılmaktadır (AFAD, 2014, s. 30). En küçük yerleşim birimi odaklı afet risk yönetiminde temel unsur bireydir. Afet tehlike ve risklerinin minimum seviyeye çekilmesinde bireyin hedef olarak seçilmesi rasyonel bir yaklaşım olmakla birlikte; eylem sürecinde kapsanacak bireylerin engel grupları açısından farklılaştıklarını da ayrıca analiz etmek gerekmektedir.

Afet ve acil durumlar, birey ve toplum açısından zarar verme kapasitesi yüksek; kısa ve hızlı reaksiyonu gerektiren bir süreçtir. $\mathrm{Bu}$ süreç, toplumda yer alan bireylerin tamamı açısından fiziksel, bedensel, ruhsal bazı zorlukları içermekle birlikte; engelli bireyler açısından daha da zorlu bir duruma dönüşebilmektedir. Engelli bireyler dünya genelinde olduğu gibi ülkemizde de toplumun önemli bir kesimini oluşturmaktadır. Engelli bireylere dair istatistiki veriler Türkiye özelinde değerlendirildiğinde; genel nüfus içinde yaş grubu ve cinsiyete göre en az bir engeli olan nüfus oranının ortalaması \%6,9 olarak hesaplanmıştır (Aile ve Sosyal Politikalar Bakanlığı, 2018, s. 31).

Ortopedik, işitme, zihinsel, görme, dil ve konuşma ve süreğen hastalıklara sahip olma gibi farklı engel gruplarındaki bireyler açısından afet ve acil durumlara dair politikaların engel grupları özelinde değerlendirilmesini gerekmektedir. Bu politikalar temelde yapısal ve yapısal olmayan risklerin azaltılması, destek ağının oluşturulması gibi afet ve acil durum öncesine dair çalışmalarla; engelli bireylere yönelik tatbikatlar, ilk yardım bilgisi gibi afet ve acil durum sırasına yönelik önlemlerdir. Bedensel engel grubuna göre yaklaşım tarzlarında ki farklılaşmalar da örneğin görme engelli bireyler için bastonunu kendi yanında tutması gibi temel reflekslerin geliştirilmeye çalışılması gerektiği vurgulanmaktadır. Tekerlekli sandalye kullanan bedensel engelli bireylerde yaklaşım tarzı biraz daha farklılaşmakta ve tekerlekli sandalyenin kaymamasına yönelik sabitleme alışkanlığı kazanma yönünde yaklaşımlar tavsiye edilmektedir (AFAD, 2011, s. 8-23-24).

\section{YÖNTEM}

\subsection{Evren ve Örneklem}

Bilimsel çalışmalar genel olarak küçük bir kitle üzerinde gerçekleştirilmekte ve çıkan sonuçlar hedef kitlenin tümüne genellenmektedir. Buradan hareketle evreni; çalışmanın problemine cevap verebilecek olan, aralarından örneklem seçilebilen edinilen sonuçların genellenebileceği bir grup olarak tanımlamak mümkündür (Altunışık vd., 2010, s. 27-142). Evren; genel ve erişilebililir olmak üzere iki gruba ayrılmaktadır. Genel evren soyut bir kavramdır. Tanımlanması kolay ancak ulaşılması zordur. Erişilebilir evren ise ulaşılması mümkün olandır. Bu açıdan somuttur (Karasar, 2011, s. 110). Bu tanımdan hareketle, araştırmanın evreni; Karabük İlin 'de yaşayan 6302 engelli vatandaş olarak belirlenmiştir (Karabük Aile, Çalışma ve Sosyal Hizmetler II Müdürlüğü, 2019). Bu çalışmada hedef kitlenin çalışma koşullarından kaynaklı cevap alma oranı, maliyet, zaman ve araştırmada kullanılacak veri toplama aracı dikkate alınarak evrenden bir örneklem belirleme sürecine başvurulmuştur (Altunışık vd., 2005, s. 128). Örneklem; araştırmanın problemine cevap vereceği düşünülen hedef kitleden, sınırları çizilmiş ve belli kurallar çerçevesinde seçilen küçük bir birim olarak tanımlanmaktadır. Bu çerçevede araştırma seçilen küçük birimler üzerinde yapılmakta ve elde edilen sonuçlar genele yansıtılmaktadır (Karasar, 2011, s. 110). Örnekleme ise hedef kitleyi temsil edebilecek bireylerin belirlenmesi 
sürecidir (Özen ve Gül, 2007, s. 397). Araştırmada tesadüfi olmayan örnekleme tekniklerinden, kolayda örnekleme tercih edilmiştir. Kolayda örnekleme, birimlerin seçiminin büyük ölçüde görüşmecilere bırakıldığı örnekleme türüdür (Nakip, 2013, s. 204). Niceliksel çalışmalarda hesaplanacak örneklem büyüklüğünün çalışmada kullanılan değişken sayısının en az beş katı olması gerekmektedir (Tavşancıl, 2002, s. 51). Ancak literatürde, evren hacminin büyüklüğü ( $N>10.000$ veya $N<10.000$ ), değişkenlerin türü (nitel veya nicel) ve güven düzeyinin göz önünde bulundurulup bulundurulmayacağı gibi belirleyiciler dikkate alınarak, örneklem hacminin hesaplanması için ilgili literatürde (Ryan, 1995, s. 36; Sekaran, 2003, s. 119) bazı formüller verilmiştir. Bu kapsamda örneklem büyüklüğünün hesaplanması için aşağıdaki örneklem hesaplama formülünden yararlanılmıştır (Arıkan, 2005, s. 87).

$$
\mathrm{n}=\frac{\mathrm{NPq}}{\frac{(\mathrm{N}-1) \times \mathrm{B}^{2}+\mathrm{Pq}}{\mathrm{Z}^{2}}}
$$

$\mathrm{n}=$ Örnekleme sayısını

$\mathrm{N}=$ Araştırmaya konu olan topluluğu

$P=$ Topluluk oranını veya tahminini

$\mathrm{q}=1-\mathrm{P}^{\prime} \mathrm{yi}$

$B=$ Katlanılabilir hata oranını

Z= İstenilen güven aralığını ifade etmektedir.

2000 ortopedik engelliden oluşan bir evrende $\alpha=0.05$ anlamlılık ve $\pm \% 5$ hata payına göre ihtiyaç duyulan örneklem sayısı 322 kişidir (Baş, 2010, s. 41; Davis ve Cosenza, 1998, s. 28; Yamane, 2001, s. 116-117). Dolayısıyla bu araştırmada hesaplanan örneklem sayısına ulaşılmıştır.

\subsection{Veri Toplama Tekniği ve Analizi}

Karabük Il'inde yaşayan ortopedik engelli vatandaşların acil durumlara/afetlere bireysel hazırlığına ilişkin faktörleri tespit etmek amacıyla yüz yüze anket tekniği kullanılmıştır. Söz konusu anket 2 bölüm şeklinde tasarlanmıştır. Birinci bölümde araştırmaya katılan kişilere ilişkin tanımlayıcı bilgilere yer verilmiştir. İkinci bölümde ise acil durumlara/afetlere bireysel hazırlığına iliş̧in ölçeğe yer verilmiştir. Ölçeğin hazırlanmasında, İnal'ın 2015 yılında gerçekleştirmiş olduğu Doktora Tezinden yararlanılmıştır (İnal, 2015). Katılımcıların acil durumlara/afetlere hazırlığa ilişkin faktörlere yönelik ifadeler 5'li Likert ölçeği formatında "1-Kesinlikle Katılmıyorum ve 5-Kesinlikle Katılıyorum" puanlandırılmıştır (Özdamar, 2004, s. 145).

Karabük Il'inde yaşayan ortopedik engelli vatandaşlardan elde edilen veriler SPSS istatistik paket programı kullanılarak analiz edilmiştir. Analizlerin ilk aşamasında veri setinin yapı geçerliliği ve iç tutarlılığı test edilmiştir (Yaşlıoğlu, 2017, s. 75). Dolayısıyla, ölçeğin yapı geçerliliğini test etmek için sıklıkla kullanılan açıklayıcı faktör analizi tekniği kullanılmıştır (Büyüköztürk vd., 2010, s. 117). Açıklayıcı faktör analizinde iki temel değer vardır. Bu değerlerden ilki olan Barlett değeri; alan çalışması sonucu elde edilen verilerin faktör analizine uygunluğunu gösteren bir değerdir. Bartlett değerinin $p<0,05$ veya $p<0,01$ olması gerekmektedir (Hair vd., 2010, s. 99). Kaiser-Meyer-Olkin (KMO) değeri ise, değişkenler setinin ne kadar ortak 
olduğunun bir göstergesi olarak kullanılmaktadır. Ölçümde elde edilecek 0.6'nın üzerinde bir sonuç faktör analizi için uygun olarak kabul edilmektedir (Tabachnick ve Fidell, 2013, s. 53). Dolayısıyla Hair vd. (2010, s. 99)'a göre, KMO oranının 0,5 veya 0,5'in üzerinde olması gerekmektedir. 0,5'in altındaki değerler değerlendirmeye uygun değildir. KMO'dan hareketle 1 'den büyük özdeğere sahip olan faktörler dikkate alınarak, veri setinin kaç faktörden oluştuğu saptanabilmektedir (Erdoğan, 2003, s. 358). Çalışmada, yaygın kullanım alanı olan ve yorumlama kolaylığı sağlayan dikey (ortagonal) döndürme yöntemlerinden biri olan Varimax Döndürme Yöntemi kullanılmıştır. Varimax döndürme yöntemi, az değişkenden hareketle faktör varyanslarının yüksek çıkmasını sağlayabilmektedir (Tavşancıl, 2002, s. 50). Ayrıca, sosyal bilimlerde faktör analizi sonucu ortaya çıkan boyutların kümülatif varyans oranlarının 0,40-0,60 aralığında olması gerekmektedir (Tavşancıl, 2002, s. 48).

Veri setinin iç tutarlılığını ölçmek amacıyla güvenilirlik analizi yapılmıştır. Güvenirlik, bir ölçüm sürecinde, ölçüm işleminin tekrarlanabilirliği ya da tekrarlardaki tutarlılıktır (Alpar, 2010, s. 411; Tavşancıl, 2002, s. 148; Ural ve Kılıç, 2013, s. 280). Güvenilirlik analizi için Alfa katsayısı (Cronbach Alpha) kullanılmıştır (Özdamar, 2004, s. 623; Erkuş, 2009, s. 132). Alfa katsayısı acil durumlara/afetlere ilişkin bireysel hazırlık ölçeğinin güvenirliliği $\alpha=0,850$ olarak tespit edilmiştir. Alfa katsayılarından hareketle ölçeğin oldukça güvenilir olduğunu söylemek mümkündür (Akgül ve Çevik, 2003, s. 436).

Analizlerin ikinci aşamasında araştırmaya katılan kişilerin demografik özelliklerinin tespiti için betimsel analizler yapılmıştır. Betimsel analizler frekans ve aritmetik ortalama olmak üzere iki değişkenden oluşmaktadır. Dolayısıyla frekanslar bir dizi nicel değişken için sıklık sayısı ve yüzdeleri gösterirken, ortalamalar yalnızca sayısal değişkenlerin aritmetik ortalamasını temsil etmektedir (Veal, 2006, s. 159; Cebeci, 2010, s. 124). Boyut ifadelerinin değerlendirmesinde; "1.00-1.80 için kesinlikle katılmıyorum, 1.81-2.60 için katılmıyorum, 2.61-3.40 için kısmen katılıyorum, 3.41-4.20 için katılıyorum ve 4.21-5.00 için kesinlikle katılıyorum" değer aralıkları dikkate alınmıştır (Özdamar, 2001, s. 145). Üçüncü aşamada katılımcıların acil durumlara/afetlere ilişkin bireysel hazırlık durumlarının demografik değişkenlere göre dağılımlarını tespit etmek amacıyla, farklılık testleri yapılmıştır. Ancak öncelikle verilerin, parametrik veya parametrik olmayan test koşularından hangisini sağladığı tespit edilmiştir. Bu kapsamda verilerin normal dağılım gösterip göstermediğine ve basıklık çarpıklık değerlerine bakılmaktadır. Normal dağılım testlerinde p değerlerinin 0,05 'ten büyük ve basıklık/çarpıklık değerlerinin de $-1,5$ ve $+1,5$ aralığında olması gerektiği ifade edilmektedir (Tabachnick ve Fidell, 2013). Dolayısıyla verilerin normal dağıldığı ve parametrik test koşullarını sağladığı tespit edilmiş ve bağımsız örneklem t-testi ve tek yönlü ANOVA testi gerçekleştirilmiştir. T testi; aralarında bağımsız olan iki grubun arasında anlamlı bir farklılık olup olmadığını belirlemeye yardımcı olan bir testtir (Yazıcıoğlu ve Erdoğan, 2004, s. 172; Arslantürk, 2001, s. 140). ANOVA ise birkaç grup arasında, ortalama skorlardaki anlamlı farklılıkları tanımlamaktadır. Gruplar arasındaki anlamlı farklılıkları belirlemede, gruplar arası varyansın grup içi varyansa oranıyla elde edilen $\mathrm{F}$ değeri göz önüne alınmıştır. Yüksek bir $\mathrm{F}$ değeri, belli bir sosyal etki değişkeninde bir veya birden fazla grubun ortalamaları arasında anlamlı bir farklılık olduğunun göstergesidir (Pallant, 2005, s. 214).

\section{BULGULAR}

\subsection{Demografik Özelliklere İlişkin Bulgular}

Karabük II'inde yaşamakta olup çalışmaya katılan ortopedik engelli kişilerin cinsiyet, medeni durum, yaş, eğitim durumu, çocuk sayısı ve engel derecesi ve sayısı ile ilgili özelliklerine yönelik 
Sürdürülebilir Bir Yönetim Paradigması: Ortopedik Engelli Bireylerin Afetlere Hazırlık Seviyeleri

A Sustainable Management Paradigm: Personal Disaster Preparadness Levels of People With Disabilities

bulgular incelenmiştir. Bu kapsamda, ortopedik engelli kişilerin demografik özellikleri Tablo 1.'de gösterilmiştir.

Tablo 1. Engelli vatandaşlara ilişkin tanımlayıcı bilgiler

\begin{tabular}{|c|c|c|c|c|c|}
\hline \multicolumn{6}{|c|}{ Demografik Özellikler } \\
\hline Cinsiyet & $\mathbf{n}$ & $\%$ & Medeni Durum & $\mathbf{n}$ & $\%$ \\
\hline Kadın & 133 & 41,3 & Evli & 153 & 47,5 \\
\hline Erkek & 189 & 58,7 & Bekar & 169 & 52,5 \\
\hline Yaş & $\mathbf{n}$ & $\%$ & Eğitim Durumu & $\mathbf{n}$ & $\%$ \\
\hline 25 Yaş Altı & 45 & 14,0 & Gitmemiş & 46 & 14,3 \\
\hline 25-30 Yaş & 103 & 32,0 & İlk ve Orta okul & 58 & 18,0 \\
\hline 31-35 Yaş & 122 & 37,9 & Lise & 87 & 27,0 \\
\hline 36 Yaş ve Üstü & 52 & 16,1 & Üniversite & 99 & 30,7 \\
\hline Engel Derecesi & $\mathbf{n}$ & $\%$ & Lisansüstü & 32 & 9,9 \\
\hline \%70 üzeri & 52 & 16,1 & Çocuk Sayısı & $\mathbf{n}$ & $\%$ \\
\hline$\% 70-\% 40$ & 155 & 48,1 & Çocuk Yok & 110 & 34,2 \\
\hline$\% 40$ Altı & 115 & 35,7 & 1 Çocuk & 108 & 33,5 \\
\hline Bir'den Fazla Engel Durumu & $\mathbf{n}$ & $\%$ & 2 Çocuk & 70 & 21,7 \\
\hline Evet & 123 & 38,2 & 3 Çocuk ve Üstü & 34 & 10,6 \\
\hline Hayır & 199 & 61,8 & Genel Toplam & 322 & 100 \\
\hline
\end{tabular}

Tablo 1.'e göre; araştırmaya ortopedik engellilerden 133'ü kadın ve 189'u erkektir. Kadın ve erkeklerden 153'ü evli ve 169'u bekârdır. Ortopedik engellilerden 45'i 25 yaşın altında, 103'ü 2530 yaşında, 122'si 31-35 yaşında ve 52'si 35 yaşın üzerindedir. Eğitim durumu itibariyle 46 kişi okula gitmemiştir. İlk ve orta okul mezunu 58 kişi, lise mezunu 87 kişi, üniversite mezunu 99 kişi ve lisansüstü mezunu 32 kişidir. Ortopedik engelli vatandaşlardan 110'unun çocuğu bulunmamaktadır. 1 çocuğu olanların sayısı 108, 2 çocuğu olanların sayısı 70 ve 3 ve üstü çocuğu olanların sayısı 34'tür. Engel derecesi bakımından katılımcılardan 52'si \%70 üstü, 155'i $\% 70-\% 40$ arası ve $115^{\prime} \mathrm{i} \% 40$ altında engele sahip olduğunu ifade etmiştir. Ayrıca katılımcılardan 199'unun tek bir engel durumu mevcutken, 123'ünün bir 'den çok engel durumuna sahip olduğu tespit edilmiştir.

\subsection{Geçerlilik ve Güvenirliliğe İlişkin Bulgular}

Ölçeğin yapı geçerliği için açıklayıcı faktör analizi, güvenirliliği için Cronbach's Alpha katsayısı ve ölçek ifadelerine katılım düzeyleri sonuçları Tablo 2'de sunulmuştur. 
Tablo 2. Acil durumlara/afetlere bireysel hazırlığına ilişkin ölçeğin geçerlilik ve güvenilirlik analizi ve aritmetik ortalama sonuçları

\begin{tabular}{|c|c|c|c|c|c|c|c|c|}
\hline Iffadeler & 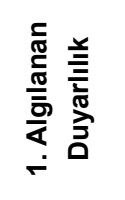 & 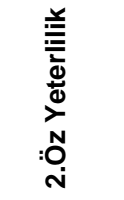 & 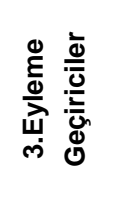 & 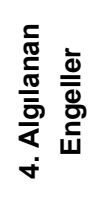 & 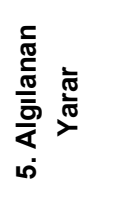 & 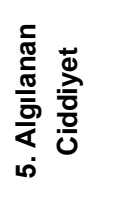 & $\bar{X}$ & 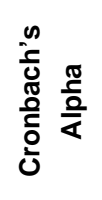 \\
\hline S1 & ,895 & & & & & & 3,316 & \multirow{7}{*}{0,958} \\
\hline S3 & ,891 & & & & & & 3,121 & \\
\hline S7 & ,890 & & & & & & 3,310 & \\
\hline S4 & ,888 & & & & & & 2,841 & \\
\hline $\mathrm{S} 2$ & ,885 & & & & & & 2,891 & \\
\hline S5 & ,847 & & & & & & 3,065 & \\
\hline S6 & ,837 & & & & & & 2,854 & \\
\hline S33 & & ,825 & & & & & 2,350 & \multirow{8}{*}{0,922} \\
\hline $\mathrm{S} 30$ & & ,822 & & & & & 2,484 & \\
\hline S27 & & ,803 & & & & & 2,661 & \\
\hline $\mathrm{S} 26$ & & ,802 & & & & & 2,549 & \\
\hline S31 & & ,795 & & & & & 2,490 & \\
\hline $\mathrm{S} 28$ & & ,791 & & & & & 2,425 & \\
\hline S32 & & ,789 & & & & & 2,416 & \\
\hline $\mathrm{S} 29$ & & ,771 & & & & & 2,605 & \\
\hline $\mathrm{S} 20$ & & & ,856 & & & & 3,332 & \multirow{6}{*}{0,920} \\
\hline $\mathrm{S} 21$ & & & ,826 & & & & 3,658 & \\
\hline $\mathrm{S} 23$ & & & ,824 & & & & 3,183 & \\
\hline $\mathrm{S} 22$ & & & ,817 & & & & 3,307 & \\
\hline $\mathrm{S} 25$ & & & ,808 & & & & 3,192 & \\
\hline S24 & & & ,804 & & & & 3,270 & \\
\hline S19 & & & & ,832 & & & 3,366 & \multirow{6}{*}{0,873} \\
\hline S15 & & & & ,806 & & & 3,403 & \\
\hline S18 & & & & ,784 & & & 3,217 & \\
\hline S17 & & & & ,748 & & & 3,378 & \\
\hline S14 & & & & ,744 & & & 3,083 & \\
\hline S16 & & & & ,742 & & & 3,136 & \\
\hline S11 & & & & & ,902 & & 2,226 & \multirow{3}{*}{0,876} \\
\hline $\mathrm{S} 13$ & & & & & ,878 & & 2,369 & \\
\hline $\mathrm{S} 12$ & & & & & ,877 & & 2,425 & \\
\hline S8 & & & & & & ,892 & 3,285 & \multirow{3}{*}{0,822} \\
\hline S9 & & & & & & ,878 & 3,291 & \\
\hline $\mathrm{S} 10$ & & & & & & ,796 & 3,279 & \\
\hline Özdeğerler & 7,170 & 5,715 & 3,437 & 2,917 & 2,380 & 2,058 & \multirow{3}{*}{2,963} & \multirow{3}{*}{0,850} \\
\hline VAO & 21,726 & 17,318 & 10,414 & 8,839 & 7,212 & 6,236 & & \\
\hline Toplam Vary & klama Ora & & & ,746 & & & & \\
\hline
\end{tabular}

Karabük'te yaşayan ortopedik engellilerden elde edilen veriler çerçevesinde, acil durumlara/afetlere bireysel hazırlığına ilişkin ölçeğine temel bileşenler (principal components) 
Sürdürülebilir Bir Yönetim Paradigması: Ortopedik Engelli Bireylerin Afetlere Hazırlık Seviyeleri

A Sustainable Management Paradigm: Personal Disaster Preparadness Levels of People With Disabilities

yöntemi ve varimax rotasyonuna göre faktör analizi yapılmıştır. Acil durumlara/afetlere bireysel hazırlığına ilişkin ölçeğin KMO değeri 0,871 ve Bartlett değeri $p<0,000$ olarak ortaya çıkmıştır. $\mathrm{Bu}$ değerlere göre acil durumlara/afetlere bireysel hazırlığına ilişkin ölçeğinin faktör analizine uygun olduğu görülmektedir. Söz konusu ölçek toplam varyansın yaklaşık \%72'sini açıklamaktadır. Ölçek, öz değeri 1'in üzerinde olan 6 boyuttan oluşmakta ve faktör yükleri de 0,35 'in üzerinde çıktığı söylenebilir. Dolayısıyla faktör yüklerinin 0,32 veya 0,35 'ten büyük olması gerektiği düşüncesinden hareketle, söz konusu ölçeğinin kullanılabilir olduğunu söylemek mümkündür (Tabachnick ve Fidell, 1989; Büyüköztürk, 2007). Ölçeğin güvenirlik katsayısı (Cronbach's Alpha $\alpha=0,850$ ) da kabul edilebilir düzeyde tespit edilmiştir. Bu sonucun $a=0,70$ 'in üzerinde olması, kullanılan ölçeğin yüksek güvenilirlikte olduğuna işaret etmektedir (Kalaycı, 2009, s. 405; Hair vd., 1998, s. 611).

Faktör 1 (Algılanan Duyarlılık), 7 ifadenin bir araya gelmesiyle oluşmuştur. Algılanan duyarlılık boyutunun varyans açıklama oranı yaklaşık \%22'dir. Bu boyuttaki ifadelerin aritmetik ortalama değerleri incelendiğinde; katılımcıların, önümüzdeki birkaç yıl içinde nispeten acil durum/afet yaşayabileceklerini $(\bar{X}=3,316)$ düşündükleri söylenebilir. Katılımcıların, acil durumlara/afetlere hazırlıkta bina dayanıklıığını artırmayı kısmen önemli buldukları ( $\bar{X}=3,121)$. Evdeki sabitlenebilecek eşyaları sabitlemeyi kısmen gereksiz buldukları $(\bar{X}=3,310)$ ve hazırlıkta acil durum/afet çantası hazırlamayı önemsemedikleri ortaya çıkmıştır ( $\bar{X}=3,841)$. Katılımcıların yaşamlarının herhangi bir döneminde acil durum/afet yaşayacaklarını göz önünde bulundurdukları $(\bar{X}=3,891)$ tespit edilmiştir. Katılımcılar, acil durum/afet olması durumunda kendilerine bir şey olmayacağına nispeten inandıkları $(\bar{X}=3,065)$ ve yakın çevreleriyle acil durumlarda/afetlerde gerekli acil iletişim numaraları hakkında konuştukları $(\bar{X}=3,854)$ görülmektedir.

Faktör 2 (Özyeterlilik), boyutu toplam varyansın yaklaşık \%17'sini açıklamakta ve 8 ifadeden oluşmaktadır. Buna göre; depremden korunmak için yaşanılan evde/binada güvenli bir yerle birlikte $(\bar{X}=2,350)$, yangın çıkmasına neden olacak tehlikeleri belirlenemeyeceği $(\bar{X}=2,484)$ düşünülmektedir. Ortopedik engelli kişilerin yangın söndürme cihazını nispeten kullanabildikleri $(\bar{X}=2,661)$ ve temel ilk yardımı uygulayabileceklerini $(\bar{X}=2,549)$ düşündükleri görülmektedir. Ancak katılımcıların, evde sabitlenmesi gereken eşyaları sabitleyemedikleri $(\bar{X}=2,490)$. Mahallelerinde yaşayanlarla birlikte acil durumlar/afetlerle ilgili tahliye planı oluşturamadıkları $(\bar{X}=2,425)$ ve basit düzeyde olsa dahi arama-kurtarma yapamayacaklarını $(\bar{X}=2,416)$ düşündükleri tespit edilmiştir. Ayrıca acil durum/afet sonrası intiyaçları olması durumunda psikolojik destek almak için gerekli hizmetlere erişemeyebileceklerini $(\bar{X}=2,605)$ düşündükleri ortaya çıkmıştır.

Faktör 3 (Eyleme Geçiriciler), boyutu toplam varyansın yaklaşık \%10'unu açıklamakta ve 6 ifadeden meydana gelmektedir. Buna göre; ortopedik engelli kişilerin aile üyelerinin, acil durumlara/afetlere bireysel hazırlık yapmanın gerekliliği konusunda nispeten bilgi verdikleri $(\bar{X}=3,332)$ ve arkadaşlarının bireysel hazırlık yapmanın gerekliliği konusunda kendilerini aydınlattığını $(\bar{X}=3,638)$ ifade etmişlerdir. Acil durum/afet konusundaki politikaların engelli kişileri hazırlıklı olmaya kısmen teşvik ettiği $(\bar{X}=3,183)$, fikirlerine önem verilen insanların acil durumlara/afetlere hazırlıklı olma konusundaki telkinlerine kısmen uyulduğu $(\bar{X}=3,307)$ ve daha önce yaşanılan acil durumlar/afetler yüzünden, neler yapılabileceğinin kısmen bilindiği $(\bar{X}=3,192)$ tespit edilmiştir. Bununla birlikte kitapçıklar, gazeteler ve broşürlerin engelli kişileri kısmen bilgilendirebildikleri ( $\bar{X}=3,270)$ düşünülmektedir. 
Faktör 4 (Algılanan Engeller), boyutu toplam varyansın yaklaşık \%9'unu açıklamakta ve 6 ifadeden meydana gelmektedir. Aritmetik ortalamalardan hareketle aile için afet planının anlaşılmasının kısmen zor olduğu $(\bar{X}=3,366)$ acil durumlara/afetlere hazırlık yapmak için kısmen paralarının olduğu $(\bar{X}=3,403)$ ifade edilmiştir. Katılımcıların bir kısmının kaderlerinde acil durumlarda/afetlerde ölmek varsa ölebileceklerini $(\bar{X}=3,217)$ ve bir kısmının acil durumlara/afetlere hazırlık yapmaktan çok daha önemli sorumluluklarının olduğunu $(\bar{X}=3,378)$ düşündükleri görülmektedir. Katılımcılar, acil durumlara/afetlere bireysel hazırlık yapmak için orta düzeyde bilgiye sahip olduklarını $(\bar{X}=3,083)$ ve bireysel hazırlık yapmanın kısmen zaman alacağını $(\bar{X}=3,136)$ düşünmektedirler.

Faktör 5 (Algılanan Yarar), boyutu toplam varyansın yaklaşık \%7'ini açıklamakta ve 3 ifadeden meydana gelmektedir. Buna göre katılımcıların acil durumlara/afetlere bireysel hazırlık yapmanın ölüm riskini azaltamayacağını $(\bar{X}=2,226)$ intiyaçlara karşılık veremeyeceğini $(\bar{X}=2,369)$ ve aile bireylerini de koruyamayacağını $(\bar{X}=2,425)$ düşündükleri tespit edilmiştir.

Faktör 6 (Algılanan Ciddiyet), boyutu toplam varyansın yaklaşık \%6'sını açıklamakta ve 3 ifadeden meydana gelmektedir. Bu çerçevede acil durum/afet yaşama intimalinin düşünülmesinin kısmen korkuya neden olduğu $(\bar{X}=3,285)$. Acil durum/afet yaşanması durumunda hayatlarında kısmen değişimlerin olabileceği $(\bar{X}=3,291)$ ve acil durum sonrasında kısmen ölüm korkusu ( $\bar{X}=3,279)$ yaşandığı tespit edilmiştir.

\subsection{Acil Durum/Afetlere Hazırlık Yapmaya İlişkin Faktörlerin Demografik Özelliklere Göre Dağılımı}

Çalışmanın bu bölümünde acil durum/afetlere hazırlık yapmaya ilişkin faktörlerin demografik özelliklere göre farklılaşma durumu ele alınmıştır. Bu kapsamda acil durum/afetlere hazırlık yapmaya ilişkin faktörlerin katılımcıların cinsiyetine göre anlamlı bir farkılık gösterip göstermediğini belirlemek için yapılan t testi sonuçları Tablo 3.'te incelenmiştir.

Tablo 3. Acil durum/afetlere hazırlık yapmaya ilişkin faktörlerin cinsiyete göre karşılaştırması

\begin{tabular}{|c|c|c|c|c|c|c|}
\hline Cinsiyet & & $\mathbf{N}$ & $\bar{X}$ & $\sigma$ & $\mathbf{t}$ & $\mathbf{P}$ \\
\hline \multirow{2}{*}{ Algılanan Duyarlılık } & 1. Kadın & 133 & 2,966 & 1,213 & \multirow{2}{*}{$-1,091$} & \multirow{2}{*}{0,276} \\
\hline & 2. Erkek & 189 & 3,120 & 1,272 & & \\
\hline \multirow{2}{*}{ Özyeterlilik } & 1. Kadın & 133 & 2,500 & ,884 & \multirow{2}{*}{0,049} & \multirow{2}{*}{0,961} \\
\hline & 2. Erkek & 189 & 2,496 & ,900 & & \\
\hline \multirow{2}{*}{ Eyleme Geçiriciler } & 1. Kadın & 133 & 3,307 & 1,087 & \multirow{2}{*}{$-0,229$} & \multirow{2}{*}{0,819} \\
\hline & 2. Erkek & 189 & 3,336 & 1,139 & & \\
\hline \multirow{2}{*}{ Algılanan Engeller } & 1. Kadın & 133 & 3,220 & ,883 & \multirow{2}{*}{$-0,762$} & \multirow{2}{*}{0,447} \\
\hline & 2. Erkek & 189 & 3,295 & 857 & & \\
\hline \multirow{2}{*}{ Algılanan Yarar } & 1. Kadın & 133 & 2,343 & 1,024 & \multirow{2}{*}{0,037} & \multirow{2}{*}{0,970} \\
\hline & 2. Erkek & 189 & 2,338 & 1,186 & & \\
\hline \multirow{2}{*}{ Algılanan Ciddiyet } & 1. Kadın & 133 & 3,320 & 1,157 & \multirow{2}{*}{0,435} & \multirow{2}{*}{0,664} \\
\hline & 2. Erkek & 189 & 3,261 & 1,251 & & \\
\hline
\end{tabular}

${ }^{*} \mathrm{p}<0,05$ 
Tablo 3.'te görüldüğü üzere; acil durum/afetlere hazırlık yapmaya ilişkin faktörlerin cinsiyete göre anlamlı bir farklılık göstermediği tespit edilmiştir. Dolayısıyla tüm boyutlarda kadın ve erkeklerinin düşüncelerinin bir birine yakın olduğu söylenebilir.

Acil durum/afetlere hazırlık yapmaya ilişkin faktörlerin katılımcıların medeni durumlarına göre anlamlı bir farklılık gösterip göstermediğini belirlemek için yapılan $t$ testi sonuçları Tablo 4.'te gösterilmiştir.

Tablo 4. Acil durum/afetlere hazırlık yapmaya ilişkin faktörlerin medeni duruma göre karşılaştırması

\begin{tabular}{|c|c|c|c|c|c|c|}
\hline \multicolumn{2}{|l|}{ Medeni Durum } & $N$ & $\bar{X}$ & $\sigma$ & $\mathbf{t}$ & $\mathbf{P}$ \\
\hline \multirow{2}{*}{ Algılanan Duyarlılık } & 1. Evli & 153 & 3,046 & 1,265 & \multirow{2}{*}{$-0,144$} & \multirow{2}{*}{0,886} \\
\hline & 2. Bekar & 169 & 3.066 & 1237 & & \\
\hline \multirow{3}{*}{ Özyeterlilik } & 1. Evli & 153 & 2,480 & ,881 & \multirow{3}{*}{$-0,337$} & \multirow{3}{*}{0,736} \\
\hline & & & & & & \\
\hline & 2. Bekar & 169 & 2,514 & ,904 & & \\
\hline \multirow{2}{*}{ Eyleme Geçiriciler } & 1. Evli & 153 & 3,361 & 1,081 & \multirow{2}{*}{0,575} & \multirow{2}{*}{0,566} \\
\hline & & & & 1110 & & \\
\hline & & & & & & \\
\hline \multirow{3}{*}{ Algılanan Engeller } & 1. Evli & 153 & 3,224 & ,907 & \multirow{3}{*}{$-0,789$} & \multirow{3}{*}{0,431} \\
\hline & & & & & & \\
\hline & 2. Bekar & 169 & 3,300 & ,830 & & \\
\hline \multirow{3}{*}{ Algılanan Yarar } & 1. Evli & 153 & 2,300 & 1,086 & \multirow{3}{*}{$-0,608$} & \multirow{3}{*}{0,544} \\
\hline & 2 R & 160 & 2070 & 1152 & & \\
\hline & & & & & & \\
\hline \multirow{3}{*}{ Algılanan Ciddiyet } & 1. Evli & 153 & 3,302 & 1,200 & \multirow{3}{*}{0,241} & \multirow{3}{*}{0,810} \\
\hline & & & & & & \\
\hline & 2. Bekar & 169 & 3,270 & 1,225 & & \\
\hline
\end{tabular}

${ }^{*} \mathrm{p}<0,05$

Tablo 4'te görüldüğg̈ üzere; acil durum/afetlere hazırlık yapmaya ilişkin faktörlerin medeni duruma göre anlamlı bir farklılık göstermediği tespit edilmiştir. Dolayısıyla tüm boyutlarda evli ve bekârların düşünceleri aynı düzeyde çıkmıştır.

Acil durum/afetlere hazırlık yapmaya ilişkin faktörlerin katılımcıların yaşlarına göre anlamlı bir farklıık gösterip göstermediğini belirlemek için yapılan One Way ANOVA testi sonuçları Tablo 5.'te gösterilmiştir. 
Tablo 5. Acil durum/afetlere hazırlık yapmaya ilişkin faktörlerin yaşa göre karşılaştırması

\begin{tabular}{|c|c|c|c|c|c|c|c|}
\hline Yaş & & $\mathbf{N}$ & $\bar{X}$ & $\sigma$ & $\mathbf{F}$ & $\mathbf{P}$ & Tukey \\
\hline \multirow{4}{*}{ Algılanan Duyarlılık } & 1. 25 Yaş Altı & 45 & 3,476 & 1,187 & \multirow{4}{*}{3,083} & \multirow{4}{*}{$0,028^{*}$} & \multirow{4}{*}{$1>2-4$} \\
\hline & 2. 25-30 Yaş & 103 & 2,898 & 1,300 & & & \\
\hline & 3. $31-45$ Yaş & 122 & 3,137 & 1,194 & & & \\
\hline & 4. 36 Yaş ve Üstü & 52 & 2,821 & 1,248 & & & \\
\hline \multirow{4}{*}{ Özyeterlilik } & 1. 25 Yaş Altı & 45 & 2,655 & ,897 & \multirow{4}{*}{2,133} & \multirow{4}{*}{0,096} & \\
\hline & 2. $25-30$ Yaş & 103 & 2,548 & ,915 & & & \\
\hline & 3. 31-45 Yaş & 122 & 2,510 & ,865 & & & \\
\hline & 4. 36 Yaş ve Üstü & 52 & 2,233 & ,877 & & & \\
\hline \multirow{4}{*}{ Eyleme Geçiriciler } & 1. 25 Yaş Altı & 45 & 3,788 & 1,190 & \multirow{4}{*}{3,574} & \multirow{4}{*}{$0,014^{*}$} & \multirow{4}{*}{$1>2-4$} \\
\hline & 2. $25-30$ Yaş & 103 & 3,195 & 1,047 & & & \\
\hline & 3. 31-45 Yaş & 122 & 3,336 & 1,158 & & & \\
\hline & 4. 36 Yaş ve Üstü & 52 & 3,147 & ,995 & & & \\
\hline \multirow{4}{*}{ Algılanan Engeller } & 1. 25 Yaş Altı & 45 & 3,237 & ,765 & \multirow{4}{*}{2,434} & \multirow{4}{*}{0,065} & \\
\hline & 2. 25-30 Yaş & 103 & 3,449 & ,827 & & & \\
\hline & 3. 31-45 Yaş & 122 & 3,168 & 940 & & & \\
\hline & 4. 36 Yaş ve Üstü & 52 & 3,147 & ,807 & & & \\
\hline \multirow{4}{*}{ Algılanan Yarar } & 1. 25 Yaş Altı & 45 & 2,222 & 1,056 & \multirow{4}{*}{1,049} & \multirow{4}{*}{0,371} & \\
\hline & 2. 25-30 Yaş & 103 & 2,495 & 1,056 & & & \\
\hline & 3. 31-45 Yaş & 122 & 2,256 & 1,182 & & & \\
\hline & 4. 36 Yaş ve Üstü & 52 & 2,333 & 1,149 & & & \\
\hline \multirow{4}{*}{ Algılanan Ciddiyet } & 1. 25 Yaş Altı & 45 & 3,377 & 1,118 & \multirow{4}{*}{0,198} & \multirow{4}{*}{0,898} & \\
\hline & 2. $25-30$ Yaş & 103 & 3,310 & 1,292 & & & \\
\hline & 3. 31-45 Yaş & 122 & 3,267 & 1,198 & & & \\
\hline & 4. 36 Yaş ve Üstü & 52 & 3,198 & 1,184 & & & \\
\hline
\end{tabular}

\section{${ }^{*} \mathrm{p}<0,05$}

Ortopedik engelli kişilerin özyeterlilik $(F=2,133, p>0,05)$, engeller $(F=2,434, p>0,05)$, yararlar $(F=1,049, p>0,05)$ ve ciddiyet $(F=0,198, p>0,05)$ boyutlarına ilişkin düşünceleri arasında anlamlı bir farklılık tespit edilmemiştir. Ancak duyarlılık $(F=3,083, p<0,05)$ ve eyleme geçirici $(F=3,574$, $p<0,05)$ faktörlere ilişkin düşünceleri arasında anlamlı farklılıklar ortaya çıkmıştır. Tukey testi sonuçlarına göre; 25 yaşın altında olan kişilerin acil durum ve afetlere karşı 25-30 yaş ve 36 yaş ve üstü kişilere göre daha duyarlı oldukları ve eyleme geçiren faktörlere daha fazla dikkat ettikleri söylenebilir.

Acil durum/afetlere hazırlık yapmaya ilişkin faktörlerin katılımcıların eğitim durumlarına göre anlamlı bir farklılık gösterip göstermediğini belirlemek için yapılan One Way ANOVA testi sonuçları Tablo 6.'da gösterilmiştir. 
Sürdürülebilir Bir Yönetim Paradigması: Ortopedik Engelli Bireylerin Afetlere Hazırık Seviyeleri

A Sustainable Management Paradigm: Personal Disaster Preparadness Levels of People With Disabilities

Tablo 6. Acil durum/afetlere hazırlık yapmaya ilişkin faktörlerin eğitim durumuna göre karşılaştırması

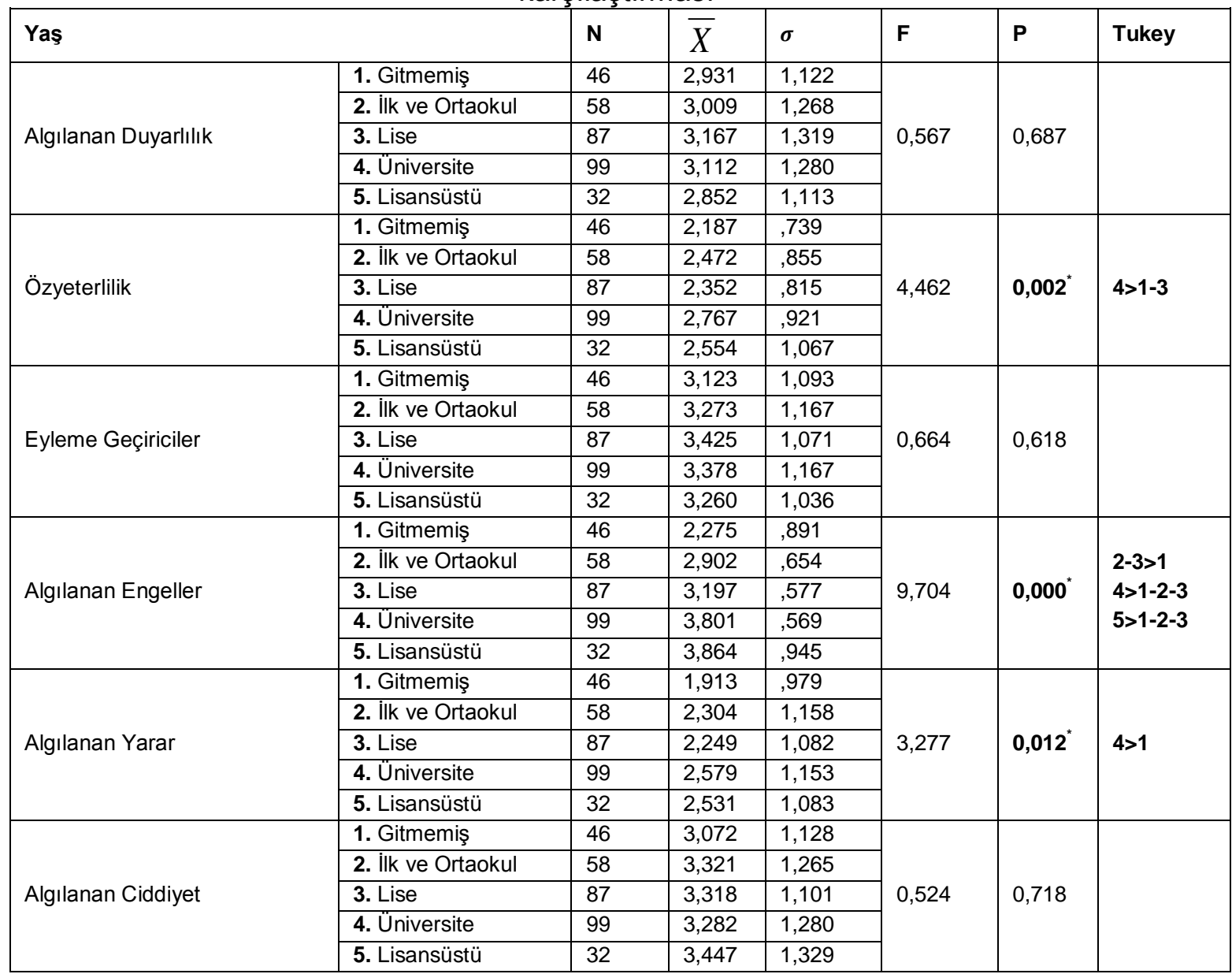

*p $<0,05$

Ortopedik engelli kişilerin duyarlılık $(F=0,567, p>0,05)$, eyleme geçiriciler $(F=0,664, p>0,05)$ ve ciddiyet $(F=0,524, p>0,05)$ boyutlarına ilişkin düşünceleri arasında anlamlı bir farklılık tespit edilmemiştir. Ancak özyeterlilik $(F=4,462, p<0,05)$, engeller $(F=9,704, p<0,05)$, yararlar $(F=3,277, p<0,05)$ faktörlere ilişkin düşünceleri arasında anlamlı farklılıklar ortaya çıkmıştır. Tukey testi sonuçlarına göre; üniversite mezunu olan kişilerin özyeterliliklerinin okula gitmemiş olanlardan ve lise mezunu olanlardan daha fazla olduğu tespit edilmiştir. Engeller konusunda ilk-orta okul ve lise mezunu olan kişilerin okula gitmemiş olanlardan daha fazla engeller yaşadıklarını düşündükleri söylenebilir. Ayrıca üniversite ve lisansüstü mezunu olan kişilerin diğer eğitim gruplarındaki kişilerden daha fazla engellerle karşılaştıkları tespit edilmiştir. Bununla birlikte üniversite mezunu olan kişilerin acil durumlara ve afetlere hazırlık yapmanın, okula gitmemiş olanlardan daha fazla yarar sağladığını düşündükleri tespit edilmiştir.

Acil durum/afetlere hazırlık yapmaya ilişkin faktörlerin katılımcıların sahip oldukları çocuk sayısına göre anlamlı bir farklılık gösterip göstermediğini belirlemek için yapılan One Way ANOVA testi sonuçları Tablo 7.'de gösterilmiştir. 
Tablo 7. Acil durum/afetlere hazırlık yapmaya ilişkin faktörlerin çocuk sayısına göre karşılaştırması

\begin{tabular}{|c|c|c|c|c|c|c|c|}
\hline \multicolumn{2}{|c|}{ Çocuk Sayısı } & \multirow{2}{*}{$\begin{array}{c}\mathbf{N} \\
109\end{array}$} & \multirow{2}{*}{$\begin{array}{c}\bar{X} \\
3,039\end{array}$} & \multirow{2}{*}{$\begin{array}{c}\boldsymbol{\sigma} \\
1,198\end{array}$} & \multirow{2}{*}{$\begin{array}{c}\mathbf{F} \\
0,468\end{array}$} & \multirow{2}{*}{$\begin{array}{c}\mathbf{P} \\
0,705\end{array}$} & Tukey \\
\hline Algılanan Duyarlılık & 1. Çocuk Yok & & & & & & \\
\hline & 2. 1 Çocuk & 109 & 3,002 & 1,288 & & & \\
\hline & 3. 2 Çocuk & 70 & 3,057 & 1,213 & & & \\
\hline & 4. 3 Çocuk ve Üstü & 34 & 3,289 & 1,376 & & & \\
\hline \multirow[t]{4}{*}{ Özyeterlilik } & 1. Çocuk Yok & 109 & 2,356 & 0,802 & \multirow[t]{4}{*}{2,602} & \multirow[t]{4}{*}{$0,050^{*}$} & \multirow[t]{4}{*}{$3>1$} \\
\hline & 2. 1 Çocuk & 109 & 2,461 & 0,906 & & & \\
\hline & 3. 2 Çocuk & 70 & 2,712 & 0,964 & & & \\
\hline & 4. 3 Çocuk ve Üstü & 34 & 2,628 & 0,908 & & & \\
\hline \multirow[t]{4}{*}{ Eyleme Geçiriciler } & 1. Çocuk Yok & 109 & 3,318 & 1,118 & \multirow[t]{4}{*}{0,971} & \multirow[t]{4}{*}{0,406} & \\
\hline & 2. 1 Çocuk & 109 & 3,209 & 1,064 & & & \\
\hline & 3. 2 Çocuk & 70 & 3,400 & 1,235 & & & \\
\hline & 4. 3 Çocuk ve Üstü & 34 & 3,553 & 1,015 & & & \\
\hline \multirow[t]{4}{*}{ Algılanan Engeller } & 1. Çocuk Yok & 109 & 3,130 & 0,789 & \multirow[t]{4}{*}{1,887} & \multirow[t]{4}{*}{0,132} & \\
\hline & 2. 1 Çocuk & 109 & 3,267 & 0,914 & & & \\
\hline & 3. 2 Çocuk & 70 & 3,438 & 0,946 & & & \\
\hline & 4. 3 Çocuk ve Üstü & 34 & 3,328 & 0,733 & & & \\
\hline \multirow[t]{4}{*}{ Algılanan Yarar } & 1. Çocuk Yok & 109 & 2,324 & 1,156 & \multirow[t]{4}{*}{0,918} & \multirow[t]{4}{*}{0,432} & \\
\hline & 2. 1 Çocuk & 109 & 2,373 & 1,144 & & & \\
\hline & 3. 2 Çocuk & 70 & 2,447 & 1,123 & & & \\
\hline & 4. 3 Çocuk ve Üstü & 34 & 2,068 & 0,898 & & & \\
\hline \multirow[t]{4}{*}{ Algılanan Ciddiyet } & 1. Çocuk Yok & 109 & 3,247 & 1,194 & \multirow[t]{4}{*}{1,302} & \multirow[t]{4}{*}{0,274} & \\
\hline & 2. 1 Çocuk & 109 & 3,302 & 1,134 & & & \\
\hline & 3. 2 Çocuk & 70 & 3,147 & 1,355 & & & \\
\hline & 4. 3 Çocuk ve Üstü & 34 & 3,637 & 1,181 & & & \\
\hline
\end{tabular}

${ }^{*} \mathrm{p}<0,05$

Tablo 7.'de görüldüğü üzere; acil durum ve afetlere hazırlık yapmaya ilişkin özyeterlilik boyutuna ilişkin düşüncenin, katılımcıların sahip oldukları çocuk sayısına göre anlamlı farklılık gösterdiği görülmektedir. Tukey testi sonuçlarına göre; 2 çocuk sahibi olan kişilerin, çocuğu olmayan kişilerden daha fazla özyeterliliklerinin olduğuna inandıkları tespit edilmiştir. Ancak acil durum ve afetlere hazırlık yapmaya ilişkin diğer faktörlerin çocuk sayısı bakımından anlamlı bir farklılık göstermediği ortaya çıkmıştır.

Acil durum/afetlere hazırlık yapmaya ilişkin faktörlerin katılımcıların sahip oldukları engel sayısına göre anlamlı bir farklılık gösterip göstermediğini belirlemek için yapılan t testi sonuçları Tablo 8.'de gösterilmiştir. 
Sürdürülebilir Bir Yönetim Paradigması: Ortopedik Engelli Bireylerin Afetlere Hazırık Seviyeleri

A Sustainable Management Paradigm: Personal Disaster Preparadness Levels of People With Disabilities

Tablo 8. Acil durum/afetlere hazırlık yapmaya ilişkin faktörlerin engel sayısına göre karşılaştırması

\begin{tabular}{|c|c|c|c|c|c|c|}
\hline \multicolumn{2}{|c|}{ Bir'den Çok Engel Durumu } & \multirow{2}{*}{$\begin{array}{l}\mathbf{N} \\
123\end{array}$} & \multirow{2}{*}{$\begin{array}{l}\bar{X} \\
3,036\end{array}$} & \multirow{2}{*}{$\begin{array}{l}\sigma \\
1,241\end{array}$} & \multirow{3}{*}{\begin{tabular}{|l|}
$\mathbf{t}$ \\
$-0,239$
\end{tabular}} & \multirow{3}{*}{$\begin{array}{l}\mathbf{P} \\
0,811\end{array}$} \\
\hline \multirow{2}{*}{ Algılanan Duyarlılık } & 1. Evet & & & & & \\
\hline & 2. Hayır & 199 & 3,070 & 1,256 & & \\
\hline \multirow{2}{*}{ Özyeterlilik } & 1. Evet & 123 & 2,497 & ,835 & \multirow{2}{*}{$-0,017$} & \multirow{2}{*}{0,986} \\
\hline & 2. Hayır & 199 & 2,498 & ,928 & & \\
\hline \multirow{2}{*}{ Eyleme Geçiriciler } & 1. Evet & 123 & 3,314 & 1,042 & \multirow{2}{*}{$-0,122$} & \multirow{2}{*}{0,903} \\
\hline & 2. Hayır & 199 & 3,330 & 1,162 & & \\
\hline \multirow{2}{*}{ Algılanan Engeller } & 1. Evet & 123 & 3,138 & ,928 & \multirow{2}{*}{$-2,065$} & \multirow{2}{*}{$0,040^{*}$} \\
\hline & 2. Hayır & 199 & 3,342 & ,819 & & \\
\hline \multirow{2}{*}{ Algılanan Yarar } & 1. Evet & 123 & 2,178 & 1,031 & \multirow{2}{*}{$-2,046$} & \multirow{2}{*}{$0,042^{*}$} \\
\hline & 2. Hayır & 199 & 2,440 & 1,163 & & \\
\hline \multirow{2}{*}{ Algılanan Ciddiyet } & 1. Evet & 123 & 3,314 & 1,167 & \multirow{2}{*}{0,333} & \multirow{2}{*}{0,739} \\
\hline & 2. Hayır & 199 & 3,268 & 1,241 & & \\
\hline
\end{tabular}

${ }^{*} \mathrm{p}<0,05$

Tablo 8.'de görüldüğü üzere; acil durum/afetlere hazırlık yapmaya ilişkin faktörlerden sadece algılanan engeller ve yararlar açısından bir farklılığın olduğu görülmektedir. Aritmetik ortalama değerlerinden hareketle; sadece bir engel durumu olanların engel durumu fazla olanlardan daha fazla engeller yaşadıklarına inandıkları ortaya çıkmıştır. Bununla birlikte sadece bir engeli olan kişilerin acil durum ve afetlere hazırlık yapmayı daha yararlı gördükleri söylenebilir.

Acil durum/afetlere hazırlık yapmaya ilişkin faktörlerin katılımcıların sahip oldukları engel derecesine göre anlamlı bir farklılık gösterip göstermediğini belirlemek için yapılan One Way ANOVA testi sonuçları Tablo 9.'da gösterilmiştir.

Ortopedik engelli kişilerin duyarlılık, özyeterlilik, eyleme geçiriciler, yararlar ve ciddiyet boyutlarına ilişkin düşünceleri arasında anlamlı bir farklılık tespit edilmemiştir. Ancak engeller $(F=3,285, p<0,05)$ boyutunda engel derecesine göre anlamlı bir farklılık olduğu ortaya çıkmıştır. Tukey testi sonuçlarına göre; engel derecesi \%70-\%40 arasında olan kişilerin engel derecesi \%40'ın altına olan kişilerden daha fazla engellerle karşılaştıkları tespit edilmiştir. 
Tablo 9. Acil durum/afetlere hazırlık yapmaya ilişkin faktörlerin engel derecesine göre karşılaştırması

\begin{tabular}{|c|c|c|c|c|c|c|c|}
\hline \multicolumn{2}{|c|}{ Çocuk Sayısı } & \multirow{2}{*}{$\begin{array}{c}\mathbf{N} \\
52\end{array}$} & \multirow{2}{*}{$\begin{array}{c}\bar{X} \\
3,151\end{array}$} & \multirow{2}{*}{$\begin{array}{c}\boldsymbol{\sigma} \\
1,241\end{array}$} & \multirow{2}{*}{$\begin{array}{c}\mathbf{F} \\
0,738\end{array}$} & \multirow{2}{*}{$\begin{array}{c}\mathbf{P} \\
0,479\end{array}$} & \multirow[t]{2}{*}{ Tukey } \\
\hline Algılanan Duyarlılık & 1. \%70 Üstü & & & & & & \\
\hline & 2. $\% 70-\% 40$ & 155 & 2,969 & 1,272 & & & \\
\hline & 3. $\% 40$ Altı & 115 & 3,132 & 1,222 & & & \\
\hline \multirow[t]{3}{*}{ Özyeterlilik } & 1. \%70 Üstü & 52 & 2,500 & 0,842 & \multirow[t]{3}{*}{0,107} & \multirow[t]{3}{*}{0,899} & \\
\hline & 2. $\% 70-\% 40$ & 155 & 2,519 & 0,899 & & & \\
\hline & 3. $\% 40$ Altı & 115 & 2,468 & 0,912 & & & \\
\hline \multirow[t]{3}{*}{ Eyleme Geçiriciler } & 1. \%70 Üstü & 52 & 3,435 & 0,981 & \multirow[t]{3}{*}{0,720} & \multirow[t]{3}{*}{0,488} & \\
\hline & 2. $\% 70-\% 40$ & 155 & 3,249 & 1,138 & & & \\
\hline & 3. $\% 40$ Altı & 115 & 3,373 & 1,146 & & & \\
\hline \multirow[t]{3}{*}{ Algılanan Engeller } & 1. \%70 Üstü & 52 & 3,236 & 0,792 & \multirow[t]{3}{*}{3,285} & \multirow[t]{3}{*}{$0,039^{*}$} & \multirow[t]{3}{*}{$2>3$} \\
\hline & 2. $\% 70-\% 40$ & 155 & 3,367 & 0,887 & & & \\
\hline & 3. $\% 40$ Altı & 115 & 3,019 & 0,924 & & & \\
\hline \multirow[t]{3}{*}{ Algılanan Yarar } & 1. \%70 Üstü & 52 & 2,032 & 1,066 & \multirow[t]{3}{*}{2,381} & \multirow[t]{3}{*}{0,094} & \\
\hline & 2. $\% 70-\% 40$ & 155 & 2,391 & 1,124 & & & \\
\hline & 3. $\% 40$ Altı & 115 & 2,411 & 1,125 & & & \\
\hline \multirow[t]{3}{*}{ Algılanan Ciddiyet } & 1. \%70 Üstü & 52 & 3,269 & 1,152 & \multirow[t]{3}{*}{0,079} & \multirow[t]{3}{*}{0,924} & \\
\hline & 2. $\% 70-\% 40$ & 155 & 3,264 & 1,229 & & & \\
\hline & 3. $\% 40$ Altı & 115 & 3,321 & 1,224 & & & \\
\hline
\end{tabular}

${ }^{*} \mathrm{p}<0,05$

\section{SONUÇLAR ve TARTIŞMA}

Afet ve acil durumlar bireyden başlayarak toplumun geneline doğru yayılan bir hazırlık sürecini gerektirmektedir. Özellikle afet olaylarında eşyaların sabitlenmesi, çök-kapan-tutun, haberleşme ağının oluşturulması gibi temel reflekslerle olası zararları en az hasarla atlatmak mümkündür. Çalışmada katılımcıların, acil durumlara/afetlere bireysel hazırlık yapmak için çok fazla bilgiye sahip olmadıkları (orta düzeyde bilgiye sahiptirler) ve bireysel hazırlıklarının zaman alacağını düşündükleri sonuçlarına ulaşılmıştır.

Araştırma sürecine katkı veren katılımcılardan önemli bir kısmının önümüzdeki birkaç yıl içinde acil durum/afet yaşayabileceklerini düşündükleri sonucuna ulaşılmıştır. Buna mukabil, katılımcıların acil durumlara/afetlere hazırlıkta bina dayanıklılığını artırmayı ve yaşanılan konuttaki sabitlenebilecek eşyaları sabitlemeyi yeterli düzeyde önemsemedikleri bulgularına da ulaşılmıştır. Katılımcıların her ne kadar gelecekte afet/acil durum yaşayacaklarına dair düşüncelerinin yüksek düzeyde olduğu sonucuna ulaşılmış olmasına rağmen; afet/acil durumlarda ilk etapta ilk yardım ve temel intiyaçlarına yönelik olarak tedbiren geliştirilen acil durum/afet çantası hazırlamayı önemsemedikleri ortaya çıkmıştır. 
Sürdürülebilir Bir Yönetim Paradigması: Ortopedik Engelli Bireylerin Afetlere Hazırık Seviyeleri

A Sustainable Management Paradigm: Personal Disaster Preparadness Levels of People With Disabilities

Afet ve acil durumlara farkındalık temelli yaklaşımlarda aile ve toplumun katkısı yadsınamaz. Özellikle engelli bireylerin aile üyelerinin ve çevresinin bu konuda önemli bir rolünün bulunduğu düşünülmektedir. Çalışma sonuçları da engelli bireylerin bu konuda başta ailesi olmak üzere çevresiyle düşük düzeyde de olsa iletişim içerisinde bulunduklarını göstermiştir. Fakat engelli bireylere, aile üyeleri tarafından verilen acil durumlara/afetlere bireysel hazırlıkların gerekliliği konusundaki bilginin yeterli düzeyde bulunmadığı sonucuna ulaşılmıştır.

Aile bireyleri ve çevre ilişkileri dışında; afet farkındalığı ve eğitimleri konusunda yazılı ve görsel basının önemli bir rolü bulunmaktadır. Çalışma sonucunda kitapçıklar, gazeteler ve broşürlerin engelli kişileri yeterli düzeyde bilgilendiremedikleri sonucuna ulaşılmıştır. Afet ve acil durumlara yönelik farkındalık temelli eğitimler birey-aile-çevre odaklı iletişim mekanizmalarını içerdiği kadar; yazılı ve görsel medya unsurlarının da dahil olması gereken kombine bir harekettir. Bu konuda yapılandırılacak olan çalışmalarda engelli bireylere yönelik özel hazırlıkların uygulanabilirliği test edilmeli ve engelli bireyler tüm süreçlere dâhil edilmelidir.

Acil durum/afetlere hazırlık yapmaya ilişkin faktörlerden sadece algılanan engeller ve yararlar açısından bir farklılığın olduğu görülmektedir. Aritmetik ortalama değerlerinden hareketle; sadece bir engel durumu olanların engel durumu fazla olanlardan daha fazla engeller yaşadıklarına inandıkları ortaya çıkmıştır. Bununla birlikte sadece bir engeli olan kişilerin acil durum ve afetlere hazırlık yapmayı daha yararlı buldukları söylenebilir.

Yürütülen çalışmanın merkezinde ortopedik engelli bireyler bulunmaktadır, bu gerçekten hareketle; ortopedik engelli bireylerin yangın söndürme cihazını nispeten kullanabildikleri $(\bar{X}=2,661)$ ve temel ilk yardımı uygulayabileceklerini $(\bar{X}=2,549)$ düşündükleri görülmektedir. Ancak katılımcıların, evde sabitlenmesi gereken eşyaları sabitleyemedikleri $(\bar{X}=2,490)$, mahallelerinde yaşayanlarla birlikte acil durumlar/afetlerle ilgili tahliye planı oluşturamadıkları $(\bar{X}=2,425)$ ve basit düzeyde olsa dahi arama-kurtarma yapamayacaklarını $(\bar{X}=2,416)$ düşündükleri tespit edilmiştir. Ayrıca acil durum/afet sonrası intiyaçları olması durumunda psikolojik destek almak için gerekli hizmetlere erişemeyebileceklerini $(\bar{X}=2,605)$ düşündükleri ortaya çıkmıştır.

Çalışma sonucunda, üniversite mezunu olan katılımcıların özyeterliliklerinin; okula gitmemiş olanlardan ve lise mezunu olanlardan daha fazla olduğu tespit edilmiştir. Engeller konusunda ilk-orta okul ve lise mezunu olan kişilerin okula gitmemiş olanlardan daha fazla engeller yaşadıklarını düşündükleri söylenebilir. Ayrıca üniversite ve lisansüstü mezunu olan kişilerin diğer eğitim gruplarındaki kişilerden daha fazla engellerle karşılaştıkları tespit edilmiştir. Bununla birlikte üniversite mezunu olan kişilerin acil durumlara ve afetlere hazırlık yapmanın, okula gitmemiş olanlardan daha fazla yarar sağladığını düşündükleri tespit edilmiştir.

\section{Teşekkür}

Yazarlar, çalışma süresince göstermiş oldukları ilgi ve yardımlarından dolayı Karabük Aile, Çalışma ve Sosyal Hizmetler İ Müdürlüğüne, Türkiye Sakatlar Derneği Karabük Şube Başkanlığına, Karabük Şafak Özel Eğitim ve Rehabilitasyon Merkezine, Safranbolu Özel Eğitim ve Rehabilitasyon Merkezine ve soruları içtenlikle yanıtlayan katılımcılara teşekkür ederler. 


\section{KAYNAKLAR}

Afet ve Acil Durum Yönetimi Başkanlığı (AFAD). (2011). Engelliler için depremde ilk 72 saat. Ankara: Afet ve Acil Durum Yönetimi Başkanlığı Yayınları.

Afet ve Acil Durum Yönetimi Başkanlığı (AFAD). (2014). Açıklamalı afet yönetimi terimleri sözlüğü. Ankara: Afet ve Acil Durum Yönetimi Başkanlığı Yayınları.

Afet ve Acil Durum Yönetimi Başkanlığı (AFAD). (2014). Türkiye, afet farkındalığı ve afetlere hazırlık araştırması. Ankara: Afet ve Acil Durum Yönetimi Başkanlığı Yayınları.

Aile ve Sosyal Politikalar Bakanlığı. (2018). Engelli ve Yaşlı Bireylere İlişkin İstatistiki Bilgiler. Araştırma Geliştirme ve Proje Dairesi Başkanlığı, Istatistiki Bülteni, Nisan. Erişim adresi: https://eyh.aile.gov.tr/uploads/pages/engelli-ve-yasli-bireylere-iliskin-istatistiki-bilgiler/2018-yilinisan-ayi-bultenini-bu-baglantiyi-kullanarak-indirebilirsiniz.pdf

Akgül, A. ve Çevik, O. (2003). İstatistiksel analiz teknikleri. SPSS’te işletme yönetimi uygulamaları. Ankara: Emek Ofset Ltd. Şti.

Akyel, R. (2005). Türkiye kamu yönetiminde afet yönetimi. Çukurova Üniversitesi Sosyal Bilimler Enstitüsü Dergisi, 14 (1) (s. 15-29) içinde.

Alpar, R. (2010). Spor, Sağlık ve Eğitim Bilimlerinde Örneklerle uygulamalı istatistik ve geçerlilikgüvenirlik. Ankara: Detay Yayıncılık.

Altunışık, R., Coşkun, R., Bayraktaroğlu, S. ve Yıldıım, E. (2010). Sosyal bilimlerde araştırma yöntemleri: SPSS uygulamalı. Sakarya: Sakarya Yayıncılık.

Altunışık, R., Çoşkun, R., Bayraktaroğlu S., Yıldırım, E. (2005). Sosyal bilimlerde araştırma yöntemleri. Sakarya: Sakarya Kitabevi Yayını.

Arca, D. (2012). Afet yönetiminde coğrafi bilgi sistemi ve uzaktan algılama. Karaelmas Fen ve Mühendislik Dergisi, 2 (2) (s. 53-61) içinde.

Arıkan, R. (2005). Araştırma teknikleri ve rapor hazırlama. Ankara: Asil Yayın.

Arslantürk, Z. (2001). Sosyal bilimciler için araştırma metod ve teknikleri. İstanbul: Çamlıca Yayınları.

Acil Yardım ve Afet Yöneticileri Derneği. (AYAYDER). (2018). 2018 Dünya afet bilgi notu. Erişim adresi: http://dosya.ayayder.org/CRED-2018-Afet-Bilgi-Notu.pdf.

Baş, T. (2010). Anket. Ankara: Seçkin Yayıncılık ve San. ve Tic. Aş.

Büyüköztürk, Ş., Çakmak, E. K., Akgün, Ö. E., Karadeniz, Ş. ve Demirel, F. (2010). Bilimsel araştırma yöntemleri. Ankara: Pegem Akademi.

Cebeci, S. (2010). Bilimsel araştırma ve yazma teknikleri. İstanbul: Alfa Basım Yayın Dağıtım.

Asian Disaster Preparedness Center (ADPC). (2005). Total disaster risk management: good practices. adresi: https://www.adrc.asia/publications/TDRM2005/TDRM_Good_Practices/GP2009_e.html.

Davis, D. ve Cosenza, R., M. (1998). Business research for decision making. Boston: Pws-Kent Publishing Company. 
Sürdürülebilir Bir Yönetim Paradigması: Ortopedik Engelli Bireylerin Afetlere Hazırık Seviyeleri

A Sustainable Management Paradigm: Personal Disaster Preparadness Levels of People With Disabilities

Dedeoğlu, N. (2011). Afetlerde Sağlık Hizmetlerinin Yönetimi ve Organizasyonu. Toplum ve Hekim, Eylül-Ekim Sayısı, 26 (5) (s. 348-365) içinde.

Dourandish, R., Zumel, N. ve Manno, M. (2007). Command and control during the first 72 hours of a joint military-civilian disaster response. Quimba Software Inc San Mateo Ca.

Erdoğan, İ. (2003). Pozitivist Metodoloji: Bilimsel araştırma tasarımı istatistiksel yöntemler analiz ve yorum. Ankara: ERK.

Erkal, T. ve Değerliyurt, M. (2009). Türkiye'de afet yönetimi. Doğu Coğrafya Dergisi, 22 (s. 147164) içinde.

Erkuş, A. (2009). Davranış bilimleri için bilimsel araştırma süreci. Ankara: Seçkin Yayıncılık.

Ersoy, Ş. (2013). Afet Raporu "Dünya ve Türkiye”, Yıldız Teknik Üniversitesi, Doğa Bilimleri Araştırma Merkezi.

Genç, F., N. (2008). Kriz iletişimi: Marmara depremi örneği, Selçuk İletişim, 5 (3) (s. 161-175) içinde.

Güler, H., H. (2008). Zarar azaltmanın temel ilkeleri. Afet Zararlarını Azaltmanın Temel İlkeleri, (s. 35-50).

Gülkan, P., Balamir, M. ve Yakut, A. (2003). Afet yönetiminin stratejik ilkeleri: türkiye ve dünyadaki politikalara genel bakış. ODTÜ, Afet Yönetimi Uygulama ve Araştırma Merkezi, Eylül.

Hair Jr., J., F., Black, W., C., Babin, B., J. ve Anderson, R., E. (2010). Multivariate data analysis: a global perspective. 7th Edition, Pearson Education, Upper Saddle River.

Hair, J., F., Anderson, R., E., Tatham, R., L. ve Black, W., C. (1998). Multivariate data analysis. 5th Edition, New Jersey: Prentice-Hall Inc.

Haddow, G., Bullock, J. ve Coppola, D., P. (2008). Introduction to emergency management. 3rd Edition, Amsterdam, Elsevier/Butterworth-Heinemann, eBook.

Hawe, G, I., Coates, G., Wilson, D., T. ve Crouch, R., S. (2012). Agent-based simulation for large-scale emergency response: a survey of usage and implementation. ACM Computing Survey, 45 (1) (s. 8-51) içinde.

Huang, J., S., ve Lien, Y., N. (2012). Challenges of emergency communication network for disaster response. In 2012 IEEE International Conference on Communication Systems (ICCS) (s. 528-532). IEEE, November.

Index for Risk Management (INFORM). (2019). Inform report 2019 shared evidence for managing crises and disasters. Erişim adresi: http://www.informindex.org/Portals/0/InfoRM/2019/Inform\%202019\%20WEB\%20spreads\%20(3). pdf?ver=201902-07-113610-123.

Işık, Ö., Aydınlıoğlu, H., M., Koç, S., Gündoğdu, O., Korkmaz, G., ve Ay, A. (2012). Afet yönetimi ve afet odaklı sağlık hizmetleri. Okmeydanı Tıp Dergisi, 28 (2) (s. 82-123) içinde.

İnal, E. (2015). Acil Durumlara/Afetlere Bireysel Hazıriiğı Değerlendirmek İçin Sağıı İnanç Modeli'ne Dayalı Ölçek Geliştirme (Yayınlanmamış Doktora Tezi). Hacettepe Üniversitesi Halk Sağlığı Enstitüsü.

Kadıoğlu, M. (2008). Modern, bütünleşik afet yönetiminin temel ilkeleri. (Ed. Kadıŏlu, M. ve Özdamar, E.) Afet Zararlarını Azaltmanın Temel İlkeleri, Ankara: JICA Türkiye Ofisi Yayınları. 
Karabük Aile, Çalışma ve Sosyal Hizmetler İI Müdürlüğü. (2019). Özel gereksinimli bireyler için afet risklerinin azaltılması çalıştayı hk. E.114204 sayılı resmi yazı.

Karasar, N. (2008). Bilimsel araştırma yöntemi. Ankara: Nobel Yayın Dağıtım.

Karasar, N. (2011). Bilimsel araştırma yöntemi. Ankara: Nobel Yayın Dağıtım.

Lichterman, J., D. (2000). A community as resource. strategy for disaster response. Public Health Reports, 115 (2-3), (s 262) içinde.

Nakip, M. (2013). Pazarlama araştırma teknikleri. 3. Baskı, Ankara: Seçkin Yayıncılık.

Odabaşı, Y. ve Barış, G. (2003). Tüketici davranışı. İstanbul: Mediacat Akademi.

Özdamar, K. (2001). SPSS ile biyoistatistik, 4. Basım, Eskişehir: Kaan Kitabevi.

Özdamar, K. (2004). Paket Programlar ile İstatistiksel Veri Analizi-ı. Genişletilmiş 5. Baskı, Eskişehir: Kaan Kitabevi.

Özcan, A., Ş. (2011). Afet ve acil durum yönetimi, mahiyeti, ilgili kurumları ve kapsamı. İdarecinin Sesi, Mart-Nisan (s. 11-16) içinde.

Özen, Y. ve Gül, A. (2007). Sosyal ve eğitim bilimleri araştırmalarında evren ve örneklem sorunu. Atatürk Üniversitesi Kazım Karabekir Eğitim Fakültesi, (15) (s. 394-422) içinde.

Özer, Y., E. (2016). Afet yönetimine giriş ve Türkiye'de örgütlenme. (Ed. Prof. Dr. Zerrin Toprak Karaman ve Prof. Dr. Asuman Altay), 1 (s. 183-200).

Özkaya, Y. (2016). Afet yönetimine giriş ve Türkiye'de örgütlenme. Afet Yönetimine Giriş ve Türkiye'de Örgütlenme, (Ed. Prof. Dr. Zerrin Toprak Karaman ve Prof. Dr. Asuman Altay), 1 (s. 201-220) içinde.

Padem, H., Göksu, A. ve Konaklı, Z. (2012). Araştırma yöntemler SPSS uygulamalı. Sarajevo: International Burch University.

Pallant, J. (2005). SPSS survival manual: a step by step guide to data analysis using SPSS. Allen and Unwin Inc., Crows Nest, New South Wales.

Ryan, C. (1995). Researching tourist satisfaction Issues, concepts, problems. London: Routledge.

Seneviratne K., Baldry, D. ve Pathirage, C. (2010). Disaster knowledge factors in managing disasters successfully. International Journal of Strategic Property Management, 14.

Sekaran, U. (2003). Research methods for business. New York: John Wiley.

Tabachnick, B. G. ve Fidel, L. S. (2013). Using multivariate statistics. USA: Pearson Education Limited.

Taştan, B. ve Aydınoğlu, A., Ç. (2015). Çoklu afet risk yönetiminde tehlike ve zarar görebilirlik belirlenmesi için gereksinim analizi. Marmara Coğrafya Dergisi, 31, Ocak.

Tavşancıl, E. (2002). Tutumların ölçülmesi ve SPSS ile veri analizi. Ankara: Nobel Yayıncılık.

Ural, A. ve Kılıç, İ. (2013). Bilimsel araştırma süreci ve SPSS veri analizi. Ankara: Detay Yayıncılık.

Varol, N. ve Kırıkkaya, E., B. (2017). Afetler karşısında toplum dirençliliği. Journal of Resilience, 1 (1) (s. 1-9.) içinde 
Veal, A., J. (2006). Research methods for leisure and tourism: a practical guide. England: Pearson Education Limited.

Yamane, T. (2001). Temel örnekleme yontemleri. Çev. A. Esin, M. A. Bakır, C. Aydın ve E. Gürbüzsel. İstanbul: Literatür Yayıncılık.

Yaşlığlu, M., M. (2017). Sosyal bilimlerde faktör analizi ve geçerlilik: keşfedici ve doğrulayıcı faktör analizlerinin kullanılması, İstanbul Üniversitesi İşletme Fakültesi Dergisi, 46 (Özel Sayı) (s. 74-85) içinde.

Yazıcıoğlu, Y. ve Erdoğan, S. (2004). SPSS uygulamalı bilimsel araştırma yöntemleri. Ankara: Detay Yayıncılık.

Yılmaz, K. (2013). Acil Hizmetlerin Eşgüdümünde Etkili Faktörler: Karabük İlinde Bir Araştırma (Yayınlanmamış Yüksek Lisans Tezi). Karabük Üniversitesi, Sosyal Bilimler Enstitüsü. 